\title{
Cetacean Interactions with Trawls: A Preliminary Review
}

\author{
D. Fertl ${ }^{1}$ \\ Marine Mammal Research Program, Texas A \& M University \\ 4700 Avenue U, Galveston, Texas 77551, USA \\ and \\ S. Leatherwood ${ }^{2}$ \\ IUCN/SSC Cetacean Specialist Group, c/o Ocean Park Conservation Foundation \\ Ocean Park, Aberdeen, Hong Kong
}

\begin{abstract}
Cetaceans interact with trawls to an undetermined extent. A preliminary review of global data indicates that individuals of 25 cetacean species (two mysticete, 23 odontocete) have been documented to have died in working trawls or discarded trawling gear. Cetacean interactions with trawls are complex, in part because both fishermen and cetaceans are drawn to areas of high prey density. Furthermore, within such areas, cetaceans are probably often attracted to trawling activities because they make it easier for the animals to exploit a concentrated food source. Individuals of 15 (possibly 16) cetacean species (13 odontocete, and one or even two mysticete) have been reported to feed in association with trawls. Animals follow working nets (feeding on stirred-up organisms or fish gilled in mesh) and also feed on discarded by-catch. Damage to gear as a result of feeding interactions or entanglement has been reported. Such damage results in (1) harm to the animals, (2) creation of negative opinions of cetaceans by fishermen (regardless of whether a cetacean or a shark is, in fact, responsible for the damage in question), and (3) loss of time and money for repair and replacement of gear. The relationships of cetaceans with trawls need to be further studied to determine what effects the trawl fisheries have on the ecology and population status of the whales and dolphins involved.
\end{abstract}

Key words: behaviour, by-catch, cetacean, feeding, fishery interaciton, mysticete, odontocete, trawl

\section{Introduction}

Interactions between various cetacean species and fisheries are geographically widespread and diverse (see reviews in Northridge, 1984, 1991; Currey et al., 1990, 1991). Interactions are potentially harmful to cetaceans (e.g. depletion of fish stocks, direct kills in fisheries, and incidental captures in fishing gear) and to humans (e.g. gear damage and depletion of commercially valuable fish stocks) (Beddington et al., 1985). Incidental catches of cetaceans in nets, especially purse seines, gillnets, and drift nets, are extensive and cause considerable mortality (Bjørge et al., 1991; Perrin et al., 1994). Mortality in trawls has been less frequently reported and all but ignored in evaluations of fisheries impacts, even though many of the causes of catches in trawls are similiar to those associated with gillnet captures.

Many fisheries in the world use trawl nets (Nedelec and Prado, 1990). Trawl nets are towed nets consisting of a cone-shaped net with a codend or bag for collecting the target species. Trawls can be bottom, midwater, or surface, and are operated from one, or occasionally two, boats to take various species of fishes, squids and crustaceans. Many national fishing fleets include a broad class of trawlers, ranging from small coastal trawlers to large catcher/processing vessels. To a large degree, net size and type (bottom, midwater, etc.) is dependent on vessel size (i.e. fishing power).

\footnotetext{
1 Current address: Minerals Management Service, U.S. Dept. of the Interior, 1201 Elmwood Park Blvd, New Orleans, LA 70123

2 Deceased January 1997
} 
Incidental takes of cetaceans exist in most areas where trawling occurs, for example, the North Sea, Bering Sea, Atlantic Ocean, Gulf of Mexico, Gulf of California, Mediterranean Sea, Indian Ocean, and waters off Australia and New Zealand (Appendix 1). Information on the numbers of animals caught and the causes of by-catches in trawls is not readily accessible (e.g. it is often embedded in the literature on gillnets); this paper compiles and summarizes existing information.

\section{Cetacean catch and composition}

Individuals of two mysticete species, 23 odontocete species, and several unidentified cetaceans (including beaked whales) have been documented to have been incidentally caught in trawls (Appendix 1 and 2$)^{1}$. The condition of incidentally caught cetaceans varies. It has been suggested that cetaceans found in nets are rarely alive when caught, and that dead or dying animals are sometimes scooped up as the nets pass (T. Loughlin, National Marine Mammal Lab., Seattle, WA, USA, pers. comm., 1991). There are a number of reports of trawls bringing up dead and decomposed bodies of cetaceans (Scheffer and Slipp, 1948; Testaverde, 1978; Perez and Loughlin, 1991), as well as skulls (Anonymous, 1979; Smith et al., 1989; Lake, MS 1995). Some workers contend that healthy cetaceans should be able to avoid trawl nets easily, since the vessels' forward progress is quite slow (van Utrecht, 1978; Niazi, 1990; T. Loughlin, pers. comm., 1991). This is clearly not the case for pinnipeds that interact with trawls, many of which are caught alive and perish in the nets [e.g. Steller sea lions (Eumetopias jubatus) (Alverson, 1992); Cape fur seals (Arctocephalus pusillus) (Shaughnessy and Payne, 1979); Hooker's sea lions (Phocarctos hookeri) (MAF Fisheries, 1991); northern fur seals (Callorhinus ursinus) (Perez and Loughlin, 1991); California sea lions (Zalophus californianus) (Miller et al., MS 1983), and New Zealand fur seals (Arctocephalus forsteri) (MAF Fisheries, 1991)]. Similarly, most cetaceans caught alive in trawls die, while few can be released alive (Appendix 1). One incident involved a minke whale (Balaenoptera acutorostrata) harpooned in Newfoundland that was found with trawl mesh web grown into its rostrum (D. E. Sergeant, Hudson, Quebec, Canada, pers. comm., 1992). It was thought that this whale had been cut out of a trawl net at some point in its life.

Why do cetaceans become caught in trawls? Trawling is an active fishing process; therefore, cetaceans are probably aware of the net and the boat's activity. Engines on trawlers produce a character-istic sound, particularly when changing stages of operation. It has been suggested that some odontocetes are able to acoustically distinguish between stages of trawl operation. Bottlenose dolphins (Tursiops truncatus) are sometimes attracted when nets are deployed (e.g. Gunter, 1954) and have been seen approaching shrimp boats to wait for by-catch to be culled (e.g. Norris and Prescott, 1961; Leatherwood, 1975; DelgadoEstrella, MS 1991). Killer whales (Orcinus orca) have been observed to do the same with trawlers in the Bering Sea (J. R. Heimlich-Boran, Cambridge, UK, pers. comm., 1991). Gruber (MS 1981) documented various reactions of bottlenose dolphins to operational stages, including following the net as it was being hauled in and, at other times, switching to boats trawling in the vicinity. On the other hand, Fertl (MS 1994) suggested that factors other than just the trawler's operational stage, such as social interactions, may play an important part in dolphin movements around shrimp boats.

A variety of biological factors can influence catches of marine mammals: species distribution, various behavioral traits, sensory capacities, and attention and searching images (Nelson, 1990). Many of the possible causes of cetacean entanglement in gillnets (IWC, 1994) can be applied to catches of cetaceans in trawls; for example, behavior (curiosity, exploration, attention and perception, social patterns, and feeding) of the cetecean appears to be an important consideration. It has been reported that there have been higher catches of cetaceans in trawls at night (Waring et al., 1990; Maigret, 1994; Baird, 1995; Crespo et al., 1997); Maigret (1994) suggests that this is perhaps the time that dolphins (e.g. Delphinus spp., and Stenella spp.) are moving slowly near the surface and are less alert, while Waring et al. (1990) noted that the reason higher catches of Delphinus spp. occur at night is not readily apparent, but did seem related to a behavioral phenomenon of the

\footnotetext{
1 A northern right whale (Eubalaena glacialis) was reported as having been caught in a trawl [the single incident was reported in O'Hara et al. (1986), Waring et al. (1990) and Kraus (1990)]. Kenney and Kraus (1993) published a correction to this; therefore, this species is not included in the tally.
} 
dolphins. Unfortunately, there is little systematic knowledge of many behavioral processes that cause cetaceans to be vulnerable to incidental takes in fishing gear (IWC, 1994).

\section{Feeding behavior}

Marine mammals frequently exploit fisheries for food. California sea lions, bottlenose dolphins, and botos (Inia geoffrensis) are known to remove fish from nearshore gillnets (Everitt et al., 1981; Cato and Prochaska, 1976; S. Leatherwood, unpubl. data, respectively); bottlenose dolphins (Cato and Prochaska, 1976; Iversen, MS 1975), rough-toothed dolphins (Steno bredanensis) (Iversen, MS 1975), false killer whales (Pseudorca crassidens) (Leatherwood et al., 1989), and killer whales (Sivasubramanian, 1964) steal hooked fish; and long-finned pilot whales (Globicephala melas) frequent traps to remove the target species, which is the squid Illex illecebrosus (Lien, 1994). It appears that some cetacean species, like pinnipeds, are attracted to trawl nets because of the easy food source they represent (e.g. Shaughnessy and Payne, 1979; Beddington et al., 1985).

Individuals of at least 15-16 cetacean species (13 odontocete and two, possibly three mysticete) have been documented to feed in association with trawling (Table 1, Appendix 3). Such associations appear to occur in all areas of the world. Individuals exploit food concentrated by trawling operations. This process is best illustrated by the long-standing relationship between bottlenose dolphins and shrimp trawlers, in which the dolphins show readiness to make use of a variety of easily procured food items (e.g. Leatherwood, 1975; Gruber, MS 1981; Corkeron et al., 1990; Fertl, MS 1994).

Animals tend to be attracted to food that is clumped or patchy in distribution (Krebs, 1978). A trawler might well be considered as a mobile patch. By remaining with this moving patch, in which available food is frequently concentrated, dolphins presumably can reduce the proportion of time spent foraging (searching for and consuming food) and possibly increase the quantity and quality of the food they do consume. The less time they spend foraging, the less energy they use. By this logic, trawling may provide an abundance and diversity of food in a small area and permit the cetaceans to select food of higher-than-usual caloric value.

Fishing operations may also open up some food niches not otherwise available to some cetaceans, such as in the Alaskan fishery for sable fish (Anoplopoma fimbria) (Matkin et al., 1986). Killer whales are often observed taking sablefish from long lines; these fish otherwise live too deep for killer whales to catch them (Matkin and Saulitis, 1994). There are two reports of humpback whales (Megaptera novaeangliae) feeding behind trawl nets (von Ziegesar, 1984 in NMFS, 1991; D.E. Sergeant, pers. comm., 1992). Sergeant suggested that, since humpback whales usually do not dive very deeply, the additional food supply brought up by trawl nets gives the whales a broader feeding resource (D.E. Sergeant, pers. comm., 1992). There is, however, little evidence to demonstrate that, for humpback whales, associating with trawl fisheries is really beneficial.

There is considerable overlap of prey species in the stomachs of cetaceans that have been feeding opportunistically around trawlers and on prey species that are targets of commercial trawl fisheries or in stomachs of target species of the commercial fishery. Analyses of stomach contents of bottlenose dolphins from the Gulf of Mexico (Barros and Odell, 1990) indicated prey composition similar to that of the non-shrimp catches of shrimp boats (Bryan, MS 1980; Pellegrin, 1982). Pellegrin (1982) calculated an overall fish/shrimp ratio (measured in tons) in by-catches of the Gulf of Mexico shrimp fishery of 9.1:1. Stomach contents of pilot whales (Globicephala spp.) caught in the North Atlantic mackerel (Scomber scombrus) fishery suggested that mackerel may be a major component of the pilot whales' diet, though feeding on Atlantic mackerel may well be an opportunistic phenomenon related only to the fishery (Waring et al., 1990; Overholtz and Waring, 1991). Analysis of stomach contents of trawl-caught Atlantic whitesided dolphins (Lagenorhynchus acutus), bottlenose dolphins and common dolphins (Delphinus spp.) southwest of Ireland showed that the dolphins were feeding on the target species of the fishery (Couperus, 1997). Couperus also noted that, based on otoliths retrieved from their stomachs, the whitesided dolphins appeared to have had a completely different diet before they arrived in the area and fed in association with trawling activities. The above observations do not necessarily indicate that the cetaceans are scavenging from trawls, but they do show that they are exploiting the same species targeted by the fisheries. Cetaceans could be feeding on fish that are ancillary to the catch (as is the case for bottlenose dolphins feeding in association with the shrimp fishery) or feeding on 
TABLE. 1. Worldwide interactions (feeding or bycatch) of cetaceans with trawl nets. $\bullet=$ reports of bycatch; $\Delta=$ reports of feeding association; $*$ possible record; $\times$ marked as unidentified pilot whale species during feeding associations, it is most likely this species; + marked as Delphinus delphis before Heyning and Perrin (1994) on genus Delphinus.

\begin{tabular}{|c|c|c|}
\hline Minke whale (Balaenoptera acutorostrata) & • & \\
\hline Fin whale (Balaenoptera physalus) & $\Delta$ & \\
\hline Humpback whale (Megaptera novaeangliae) & • & * \\
\hline Finless porpoise (Neophocaena phocaenoides) & • & \\
\hline Dall's porpoise (Phocoenoides dalli) & $\bullet$ & \\
\hline Harbor porpoise (Phocoena phocoena) & $\bullet$ & \\
\hline Vaquita (Phocoena sinus) & • & \\
\hline Sperm whale (Physeter macrocephalus) & • & \\
\hline Commerson's dolphin (Cephalorhynchus commersonii) & $\bullet$ & \\
\hline Heaviside's dolphin (Cephalorhynchus heavisidii) & $\bullet$ & \\
\hline Hector's dolphin (Cephalorhynchus hectori) & & \\
\hline Common dolphin (Delphinus spp.)+ & & \\
\hline Short-finned pilot whale (Globicephala macrorhynchus) & • & \\
\hline Long-finned pilot whale (Globicephala melas) & • & $x$ \\
\hline Risso's dolphin (Grampus griseus) & $\bullet$ & \\
\hline Atlantic white-sided dolphin (Lagenorhynchus acutus) & & \\
\hline White-beaked dolphin (Lagenorhynchus albirostris) & • & \\
\hline Peale's dolphin (Lagenorhynchus australis) & • & \\
\hline Pacific white-sided dolphin (Lagenorhynchus obliquidens) & $\bullet$ & \\
\hline Dusky dolphin (Lagenorhynchus obscurus) & $\bullet$ & \\
\hline Killer whale (Orcinus orca) & & \\
\hline Tucuxi (Sotalia fluviatilis) & $\Delta$ & \\
\hline Indo-Pacific hump-backed dolphin (Sousa chinensis) & $\Delta$ & \\
\hline Striped dolphin (Stenella coeruleoalba) & & \\
\hline Atlantic spotted dolphin (Stenella frontalis) & & \\
\hline Spinner dolphin (Stenella longirostris) & $\bullet$ & \\
\hline Bottlenose dolphin (Tursiops truncatus) & & \\
\hline Franciscana (Pontoporia blainvillei) & • & \\
\hline Northern bottlenose whale (Hyperoodon ampullatus) & $\Delta$ & \\
\hline
\end{tabular}

the fishery target species (such as the association of pilot whales with the Atlantic mackerel fishery in the northeastern United States) (see Appendix 3 for sources). A cetacean could be attracted to nets because of prey caught in the trawl nets, as well as scavengers feeding on fish caught by the nets. One dramatic example of the latter was reported for the Bering Sea, where killer whales pursued Steller sea lions that were waiting to feed on discarded bycatch from a trawler (Branson, 1971).

The bottlenose dolphin is the cetacean species most often documented to feed in association with trawls. Leatherwood (1975) describes three feeding patterns that bottlenose dolphins use when associating with shrimp boats: (1) foraging behind working boats, (2) feeding on trash fish discarded or fallen from the net, and (3) feeding on fish attracted to non-working shrimpers. The vast majority of episodes of cetaceans feeding around trawls involve feeding behind working trawlers (Appendix 3). In such instances, the animals typically follow a vessel and feed on organisms stirred up by the trawl, pick out fish entangled in the net's mesh, or possibly feed on fish that pass through the mesh. It is reasonable to assume that in all three of these circumstances the prey are dead, injured, or disoriented and therefore easier for the dolphins to catch than individuals of the same species that are healthy and actively avoiding capture. Bottlenose dolphins, pilot whales (Globicephala spp.), and Indo-Pacific hump-backed dolphins (Sousa chinensis) have been observed feeding around the mouth of nets (bottlenose dolphins: Fertl, MS 1994; Delgado-Estrella, MS 1991; Leatherwood, unpubl. data; pilot whales: 
Waring et al., 1990; Indo-Pacific hump-backed dolphins: S. Leatherwood, unpubl. data), presumably on fish escaping the net's pathway. In interviews, many Gulf of Mexico shrimpers told one of us that they had witnessed bottlenose dolphins entering trawl nets to feed. Crespo and Corcuera (1990) provided similiar reports of dolphins (unid. species) in Argentine waters moving into and out of trawl net mouths to feed

Opportunistic feeding by cetaceans in association with fisheries is perhaps best exemplified by cetaceans feeding on discarded bycatch. This behavior has been described for killer whales in the Bering Sea and off the Shetland Islands (Teshima and Ohsumi, 1983; Couperus, 1994, respectively) and bottlenose dolphins in the Gulf of Mexico (e.g. Caldwell and Caldwell, 1972; Leatherwood, 1975; Gruber, MS 1981), southeastern United States (Davis, 1988), and Moreton Bay, Australia (e.g. Corkeron et al., 1990; Wassenberg and Hill, 1990). Typically, the animals have been seen to wait alongside the vessel for bycatch to be discarded. Wassenberg and Hill (1990) calculated that dolphins scavenging behind a trawler can eat about $86 \%$ of fish discarded from a single trawl. In observations of bottlenose dolphins feeding on trash fish, the dolphins were found to show preferences for some prey species over others (Shane, MS 1977; Gruber, MS 1981; Corkeron et al., 1990; Wassenberg and Hill, 1990; Fertl, MS 1994).

Leatherwood (1975) suggested that bottlenose dolphins have learned the advantages of following and feeding in conjunction with shrimp boats. Females with calves, in particular, have been observed following shrimp boats, and it has been speculated that the calves learn this foraging behavior by observation and participation (Shane et al., 1986). Studies of other marine mammals, such as sea otters (Enhydra lutris) and killer whales, have suggested that youngsters develop feeding skills through imitation of the mother's feeding behaviors (Riedman et al., 1989; Guinet, 1991 and Guinet and Bouvier, 1995). It has been speculated that females with calves may be taking advantage of the concentrated food resource provided by shrimp boats to meet increased energetic needs due to lactation (Fertl, MS 1994; P. Corkeron, Univ. of Sydney, Sydney, Australia, pers. comm., 1993). Lactating mammals have greater energetic needs, and may need to eat greater quantities of food or change to a diet richer in nutrients (Bernard and
Hohn, 1989). Caloric consumption by captive, lactating bottlenose dolphins in the six months following parturition increases from $129 \%$ to $204 \%$ of that of resting dolphins (Ridgway et al., 1992). The association of cetaceans with trawls may well be a strategy to increase the rate of feeding, while decreasing the energy expenditure associated with foraging.

The association of cetaceans with trawls indicates the behavioral flexibility of these animals to capitalize on human activities. This feeding pattern may be beneficial in that it reduces time required to forage, and provides the animals with an easier way to obtain food that is outside their usual foraging depths or otherwise too energetically costly for them to exploit. Associations with working trawlers may be harmful in that it may expose dolphins to greater risk of injury or death. Corkeron et al. (1990) noted that bottlenose dolphins spent seemingly "unnecessary" time taking preferred items in shrimp boat by-catches, appearing to place themselves at a greater risk of shark attack; at least one dolphin was known to have been bitten by a shark while following a trawler. There also may be cause for concern that generations of dolphins that have fed largely or exclusively in association with such fisheries may be at disadvantage when these fisheries collapse.

\section{Gear damage during feeding}

Many trawl fishermen blame dolphins for holes in their nets (Gunter, 1942, 1944, 1951, 1954; Cadenat, 1957; Ravel, 1963; Reynolds, 1985; Northridge, 1984, 1991; dos Santos and Lacerda, 1987; Bearzi and Notarbartolo di Sciara, 1992; Consiglio et al., 1992; Silvani et al., 1992; Fertl, MS 1994), but such damage may likely be as a result of sharks tearing at the nets (as reported in Shane, MS 1977; Gruber, MS 1981; Delgado-Estrella, MS 1991; Fertl, MS 1994) as from dolphins attempting to pull fish out of the nets. The areas with the most frequent complaints appear to be the Mediterranean and the Gulf of Mexico, and the species most fishermen blame is the bottlenose dolphin (when species was designated). Gulf of Mexico shrimpers insisted that dolphins were "attacking" the nets in response to low fish productivity in the area (Fertl, MS 1994).

Attempts to reduce damage to trawl nets on the Gulf Coast of the United States and the Mediterranean have included the use of firecrackers detonated near the animals and bullets fired into 
the water nearby (Gunter, 1944; Cadenat, 1957; Reynolds, 1985; Bearzi and Notarbartolo di Sciara, 1992; Consiglio et al., 1992; Silvani et al., 1992; Fertl, MS 1994). Acoustical deterrents appear to be successful only for a very short time period, if at all (Caldwell and Caldwell, 1972; Consiglio et al., 1992). Non-acoustical methods used by shrimp fishermen include tying ribbons to nets and installing an extra skirt on the net to frighten dolphins away; these methods have met with mixed results. On the coast of the Adriatic and Tyrrhenian seas, there is a story of fishermen putting a fake dolphin in the net - like a scarecrow - to scare dolphins away. The results were apparently good for a few days, but then the dolphins "saw the cheating" and tore the nets with their teeth (L. Marini, Univ. of Rome, Rome, Italy, pers. comm., 1993).

Holes in nets and incidental captures of dolphins can result in loss of fishing time, while the crew disentangles carcasses or live animals, and loss of money while crews fix or replace damaged gear. Dolphins sometimes blunder into a tow or handling line and do minor damage while struggling to free themselves (Leatherwood and Reeves, 1982; Fertl, MS 1994). Netting and rope may be lost in trying to free live or dead cetaceans. In one instance, a net was cut to release a bottlenose dolphin caught in a groundfish trawl (C. Pharr, NMFS, Pascagoula, Mississippi, USA, pers. comm., 1991). In another, a stranded bottlenose dolphin from Mississippi was found lodged in a complete, small trawl net (stranding record SE3983, Southeast U.S. Stranding Network Region). Northridge (1988) reported an incident of a pilot whale (Globicephala spp.) that became lodged in a trawl and drowned; the net was subsequently lost.

\section{Distribution of entanglements}

It is not surprising that cetaceans and humans that exploit similar food resources have overlapping ranges. Potential cetacean and trawl fishery interactions are likely to occur when spatial and temporal habitat use coincides, for example, Atlantic white-sided dolphins and trawlers both taking migrating mackerel southwest of Ireland (Couperus, 1997) and white-beaked dolphins (Lagenorhynchus albirostris) and midwater trawlers taking spawning herring in the North Sea (Northridge, 1988). The frequency with which individuals of a cetacean species are caught accidentally in trawls is a function of the abundance of that species in a fishing area, as well as operational characteristics of the fishery. For abundant species in heavily fished areas, it would be surprising if some animals were not taken in fishing nets. For example, high catch rates in the Northwest Atlantic may be related to the distribution of fishing effort in particular areas of high pilot whale density (Northridge, 1991). Harbor porpoises (Phocoena phocoena), generally found near-shore, may be particularly susceptible to incidental captures because inshore areas are often heavily fished (Nelson, 1990). Movements and seasonal changes in distribution of a species will be reflected in seasonal and geographic differences in net catches (it should be noted that in some fisheries, the fishing effort in certain areas may be very different interannually, depending on the market situation, quota regulations, and behavior of fish schools, particularly if they are a pelagic species). Some species' abundance, however, may have little connection to catch rates. For example, the size and behavior of the animal, and net size could determine the possibility of the animal's being caught.

\section{Gear characteristics}

Individuals of more cetacean species are caught in mid-water trawls than in bottom trawls. Northridge (1988) discussed several reasons why mid-water gear is more likely to catch cetaceans. First, mid-water nets generally target small pelagic fish species, which are often the same species preyed upon by marine mammals. Second, midwater gear is generally towed at relatively high speeds. Finally mid-water trawls are generally much larger than most demersal trawls. Niazi (1990) speculated that the smaller size and openings of bottom trawls in Pakistan make them harmless to finless porpoises (Neophocaena phocaenoides). Whether he felt the trawl openings were small enough to deter animals from entering the nets is not clear. Pair trawlers tow nets with higher headlines and greater overall dimensions and they tow them faster than single trawlers (Anonymous, 1981; Kuiken et al., 1994); pair trawlers account for about $50 \%$ of all cetacean catches in waters off New Zealand, with gillnets and single trawlers making up the remainder (Anonymous, 1981).

Northridge (1988) and Waring et al. (1990) speculated that the mouth in many trawl nets permits dolphins to enter and get caught. It is generally thought that some individuals enter the trawl and become trapped when the boat stops hauling and the trawl entrance collapses 
("haulback") (Clausen and Andersen, 1988; Northridge, 1988; Waring et al., 1990) or when the net is being put out into the water ("shot") (Moreno, 1993), and then the net is relatively shapeless and slow-moving. This is the time when many pinnipeds appear to become caught (e.g. MAF Fisheries, 1991). It is highly probable that many cetaceans trapped during shooting or haulback are alive when caught, but die because the nets are kept in the water for long periods of time before being checked. Bottlenose dolphins in the Gulf of Mexico have been reported with their rostrums caught in the net mesh, perhaps when pulling fish scraps from the nets (Leatherwood and Reeves, 1982; R. Ford, NMFS, Pascagoula, Mississippi, USA, pers. comm., 1991); one bottlenose dolphin in the Gulf of Mexico was caught by its teeth in the net, but was released alive (Fertl, MS 1994). Ironically, there are two separate reports of bottlenose dolphins that were found caught in turtle excluder devices (installed on trawls to allow turtles caught as by-catch to escape from shrimp trawls) (Burn and Scott, 1988; Fertl, MS 1994).

\section{Behavior and social structure}

Cetacean social structure may play a significant role in incidental capture potential. Incidental catches of pilot whales (Globicephala spp.), very social cetaceans, often involve multiple animals (G. Waring, NMFS, Woods Hole, Massachusetts, USA, pers. comm. 1991). Cetaceans that forage in dense groups, such as common dolphins (Delphinus spp.) and pilot whales (Globicephala spp.), often become victims of trawls (Waring et al ., 1990). Where cetaceans feed in the water column also affects how frequently they are caught. For example, the frequent feeding at midwater depths may account for the large number of cetaceans (e.g. pilot whales, Globicephala spp., common dolphins, Delphinus spp., and harbor porpoise) trapped in mid-water trawls.

It appears that of all cetaceans captured, a disproportionate number are young animals (Teshima and Ohsumi, 1983; Corkeron et al., 1990; Niazi, 1990; Vidal, MS 1990; V. Cockcroft, Port Elizabeth Museum, Humewood, South Africa, pers. comm., 1992). Most of the common dolphins (Delphinus spp.) killed in squid (Loligo) and Atlantic mackerel fisheries are likely sexually immature (Waring et al., MS 1990). Vidal (MS 1990) suggested that because vaquita (Phocoena sinus) calves move too slowly they become trapped in trawls. It is also probable that young cetaceans are caught because of their inexperience with fishing gear (Nelson, 1990). Young animals may learn safe movements around nets by watching conspecifics. Phocoenids have a shorter dependency period and shorter lifespan than delphinids (Gaskin, 1984; Perrin and Reilly, 1984), and thus, have less opportunity to learn from their mothers or conspecifics. Tyack (1986) reviewed the importance of a long period of parental care as it relates to the importance of social learning in odontocetes. It is also probable that younger animals are not as attentive as adults to the dangers that nets pose, and become caught accidentally, panic, and are unable to free themselves. Young cetaceans may also be greater "risk takers" than adults (Nelson, 1990), as is true in most animal species (Fagen, 1981).

Lack of attention (also discussed in IWC, 1994, for gillnet captures) may be another reason for incidental takes. Mature cetaceans, as well as young and inexperienced individuals, may become "careless" around nets. Attention to social activity, such as play, may distract individuals. Trawl fishermen insist that dolphins do not get caught in their nets because they are too fast and too smart (Davis, 1988; Moreno, 1993; Fertl, MS 1994). Bottlenose dolphins sometimes drown when they are caught around the tail stock in the hanging line of the trawl (Fertl, MS 1994). We have witnessed several episodes of bottlenose dolphins playing with lines while nets were being pulled.

\section{Additional considerations}

Discarded or lost gear. Entanglement in discarded gear is an often over-looked, but important, problem. Trawl fisheries are major activities in the North Pacific Ocean, with $5500 \mathrm{~km}$ of nets in use (Uchida, 1985). When proportions of litter were studied on southeastern Alaska beaches, $76-85 \%$ by weight consisted of trawl-web fragments (Low et $a l .$, 1985). There are many reports of marine mammals becoming entangled in trawl webbing (O'Hara et al., 1986), but few data on the numbers of entangled animals that die. Fowler (1982) has shown that entanglement in trawl net fragments could account for about a $5 \%$ mortality rate of northern fur seals a year. These fragments may act as ghost nets, not unlike fragments of monofilament gillnet. It is probable that some of these fragments may have food organisms in them. One sperm whale (Physeter macrocephalus) stranded in Oregon was reported to have had approximately one liter of tightly packed trawl nets in its stomach (Mate, 1985). De- 
spite the link between frequency of entanglement and resultant death, there seems little doubt that this, and perhaps other kinds of operational interaction arising from the increased trawling in the Bering Sea, is a major factor in determining the otherwise inexplicable decline of the northern fur seal (Beverton, 1985) and Steller sea lion (Alverson, 1992).

Ecological/Resource Depletion. There has been some concern that trawling may disperse and alter distributional features of prey species for some cetaceans and other marine mammals. Biomass of epifaunal organisms has dropped dramatically in some areas due to trawling, and changed the dominant species of fish caught (Sainsbury, 1988 in Hutchings, 1990). The Steller sea lion has already experienced a population collapse, reputedly from the vast overfishing in its habitat (Alverson, 1992). Populations of these sea lions are suggested to be in danger because of a nutritional deficiency resulting from the absence of fatty fishes in their diet (Alverson, 1992). Similar impacts may gravely endanger cetaceans in areas of heavy trawl-fishing, such as the Bering Sea, Mediterranean Sea, and Gulf of Mexico. It has been thought that shrimp trawling operations have a net beneficial effect for bottlenose dolphins, providing more easily captured food (Wang et al., 1994); however, while trawling (of any type) may open up new feeding niches, it probably destroys others. As noted earlier in this paper, bottlenose dolphins may currently be taking advantage of the easily concentrated food resource that shrimp boats provide, but future generations may be disadvantaged by shifts, or even severe declines, in prey species. Trawl fisheries not only affect takes of target species, but also the food web. For example, high-seas trawl fisheries off Patagonia take hake (Merluccius hubbsi) as one of their targets. Hake is a predator of anchovy, the main prey item of dusky dolphins (Lagenorhynchus obscurus) (Crespo et al., 1997). Unbalancing of the marine ecosystem may cause shifts that initially seem beneficial to the dolphins, but may soon or ultimately prove detrimental to all participants in the system.

\section{Concluding Remarks}

Intensive trawling occurs in many areas of the world, with resulting incidental catches of cetaceans. However, considering the intensive trawl fisheries that exist in some areas, it appears that comparatively smaller numbers of cetaceans are caught by trawls in contrast to other fishing gear such as purse seines (Coe et al., 1985; Bjørge et al., 1991) and gillnets (Leatherwood, 1994; Perrin et al., 1994).

Cetacean distribution, social structure, and behavior are important biological factors that interact with characteristics of trawl nets to cause entanglements. Cetacean feeding habits may be important in many of the incidental captures. In fact, common dolphins (Delphinus spp.) in New Zealand (Anonymous, 1982) and bottlenose dolphins in the Gulf of Mexico (Leatherwood, 1975) feed on fish attracted to non-working trawlers; when boats are anchored at night, their lights often attract fish and other animals to feed. Trawlers may make it easier for individuals, especially juveniles, old individuals, or mothers with calves, to capture food that is otherwise difficult (in volume) for them to catch.

As also reported by the IWC (1994): entanglements may occur where the target species are prey or potential prey for cetaceans; the fish caught are not prey species but cetaceans are attracted to the nets because other potential prey are associated with the net; the target and incidental species are seeking similar prey; or the cetaceans and fisheries occur in the same vicinity for reasons related to physiography and biological productivity. In general, the behavior of cetaceans near nets is poorly understood. Several additional causes for these bycatches may be an individual's inattention or inexperience, and patterns of social interactions.

In summary, the evidence summarized in this report, while preliminary, suggests that fishing trawls can represent a significant source of cetacean mortality and that inadequate attention has been paid to this problem to date. Existing data do not permit us to determine the relative incidence of such mortalities among the different trawl types: sample sizes are too small, and many areas have no observer coverage. However, it seems likely that the greatest potential for conflict exists with mid-water and surface trawls operating in areas of high cetacean density, notably where both fishermen and cetaceans target the same prey.

It can probably be taken for granted that, as with gillnet fisheries, the number of cetacean mortalities reported by trawl fishermen underrepresents the 
true situation. Fear of prosecution or other legal sanctions (and absence of observers) probably results in many or most incidentally killed animals being discarded. Because an assessment of this problem is not possible without directed research, we recommend that an observer program be established to collect information on the frequency of cetacean mortality among the various types of trawling operations. Observer data would also permit an assessment of the extent to which mortality rates differ by area and by target fish species. Inevitably, this research must be conducted in concert with studies to address broader biological and management questions relating to abundance, population structure, and seasonal movements of the cetacean species concerned.

\section{Acknowledgements}

Drafts of this manuscript were improved by comments from P. Clapham, V. Cockcroft, A. S. Couperus, T. Jefferson, R. R. Reeves, J. Sigurjonsson, J. Stern, B. Würsig, and an anonymous reviewer. T. Jefferson, A. Schiro, and L. Haase helped locate and double-check pertinent references. Communications with the following people provided valuable insight, vital documents, and unpublished numbers: R. Baird, S. J. Baird, J. Barlow, G. Bearzi, P. Best, B. Clausen, V. Cockcroft, P. Corkeron, H. Coulson, A. S. Couperus, K. Dudzinski, M. Earle, R. Ford, J. Gruber, J. Heimlich-Boran, T. Jefferson, R. Kenney, T. Loughlin, L. Marini, R. Mattlin, P. Moreno, K. Mullin, G. Notarbartolo di Sciara, M. Perez, C. Pharr, C. Rogers, G. Rountree, D. E. Sergeant, G. Silber, E. Slooten, K. Teshima, O. Vidal, K. Wang, and G. Waring. R. Ortiz and J. Rodriguez helped with translations. This represents contribution number 57 of the Marine Mammal Research Program, Texas A\&M University at Galveston.

\section{References}

ABEL, G. R., and S. LEATHERWOOD. 1985. Live captures of cetaceans off Taiwan and western Australia, 1978-1981. Rep. Int. Whal. Comm. 35: 429-430.

ALVERSON, D. L. 1992. A review of the commercial fisheries and the Steller sea lion (Eumetopias jubatus): the conflict arena. Rev. Aquat. Sci., 6: 203-256.

ANDERSEN, S. H., and B. CLAUSEN. MS 1983. Bycatches of the harbour porpoise, Phocoena phocoena, in Danish fisheries 1980-81, and evi- dence for over-exploitation. Doc. SC/35/SM14 presented to IWC Sci. Comm., 10 p.

ANON. 1979. South Africa's progress report on cetacean research. Rep. Int. Whal. Comm., 29: 129-130.

1981. New Zealand's progress report on cetacean research, June 1979-May 1980. Rep. Int. Whal. Comm., 31: 201-202.

1982. New Zealand's progress report on cetacean research, May 1980-May 1981. Rep. Int. Whal. Comm., 32: 189-195.

1988a. New Zealand's progress report on cetacean research, May 1986-May 1987. Rep. Int. Whal. Comm., 38: 204.

1988b. Sweden's progress report on cetacean research, June 1986-April 1987. Rep. Int. Whal. Comm., 38: 208.

1989a. Netherlands' progress report on cetacean research. Rep. Int. Whal. Comm., 39: 184-185.

1989b. New Zealand's progress report on cetacean research. Rep. Int. Whal. Comm., 39: 185187.

1990a. Australia's progress report on cetacean research. Rep. Int. Whal. Comm., 40: 183-188.

1990b. New Zealand's progress report on cetacean research. Rep. Int. Whal. Comm., 40: 202205.

1990c. United Kingdom's progress report on cetacean research. Rep. Int. Whal. Comm., 40: 210.

1991a. Australia's progress report on cetacean research. Rep. Int. Whal. Comm., 41: 223-229.

1991b. New Zealand's progress report on cetacean research. Rep. Int. Whal. Comm., 41: 245248.

BAIRD, R. W., P. J. STACEY, and K. M. LANGELIER. MS 1991. Strandings and incidental mortality of cetaceans on the B. C. coast, 1990. IWC Sci. Comm., Doc. SC/43/01.

BAIRD, S. J. (compiler) 1995. New Zealand fisheries assessment working group 95/1: Nonfish species and fisheries interactions working group report April 1995. MAF Fisheries Greta Point, Wellington. $24 \mathrm{p}$.

BAKER, A. N. 1978. The status of Hector's dolphin, Cephalorhynchus hectori (Van Benden), in New Zealand waters. Rep. Int. Whal. Comm., 28: 331334.

BARLOW, J., R. W. BAIRD, J. E. HEYNING, K. WYNNE, A. M. MANVILLE II, L. F. LOWRY, D. HANAN, J. SEASE, and V. N. BURKANOV. 1994. $A$ review of cetacean and pinniped mortality in coastal fisheries along the west coast of the USA and Canada and the east coast of the Russian Federation. Rep. Int. Whal. Comm., Special Issue 15: 405-426.

BARROS, N. B., and D. K. ODELL. 1990. Food habits of bottlenose dolphins in the southeastern United States. In: The bottlenose dolphin. S. Leatherwood and R. R. Reeves (eds.), Acad. Press, San Diego, Calif., p. 309-328. 
BARROS, N. B., and R. L. TEIXEIRA. 1994. Incidental catch of marine tucuxi, Sotalia fluviatilis, in Alagoas, northeastern Brazil. Rep.Int. Whal. Comm., Special Issue 15: 265-268.

BEARZI, G., and G. NOTARBARTOLO DI SCIARA. 1992. Preliminary observations of bottlenose dolphins near the island of Tavolara, Sardinia. Abstract, Eur. Cet. Soc., 6th Annual Conference, Remo, Italy, 20-22 Feb.

BEARZI, G., G. NOTARBARTOLO DI SCIARA, and L. BONOMI. 1992. Bottlenose dolphins off Croatia: a socio-ecological study. Abstract, Eur. Cet. Soc., 6th Annual Conference, Remo, Italy, 20-22 Feb.

BEDDINGTON, J. R., R. J. H. BEVERTON, and D. M. LAVIGNE (eds). 1985. Marine mammals and fisheries. George Allen \& Unwin, London. 354 p.

BENKE, H., H. KREMER, and A. F. PFANDER. 1991. Incidental catches of harbour porpoises (Phocoena phocoena Linnaeus 1758) in the coastal waters of Angeln and Schwansen (Schleswig-Holstein, FRG) from 1987-1990. Abstract, Eur. Cet. Soc., 5th Annual Conference, Sandefjord, Norway, 21-23 Feb.

BERNARD, H. J., and A. A. HOHN. 1989. Differences in feeding habits between pregnant and lactating spotted dolphin (Stenella attenuata). J. Mammal, 70: $211-215$.

BEVERTON, R. J. H. 1985. Analysis of marine mammalfisheries interaction. In: Marine mammals and fisheries. J. R. Beddington, R. J. H. Beverton, and D. M. Lavigne (eds.), George Allen \& Unwin, London. p. 3-61.

BJØRGE, A., R. L. BROWNELL, Jr., W. F. PERRIN, and G. P. DONOVAN. (eds.). 1991. Significant direct and incidental catches of small cetaceans. Rep. Int. Whal. Comm., 42: 178-255.

BRANSON, J. 1971. Killer whales pursue sea lions in Bering Sea drama. Comm. Fish. Rev., 33: 39-40.

BRYAN, C. E. MS 1980. Organisms captured by the commercial shrimp fleet on the Texas brown shrimp (Penaeus actecus Ives) grounds. M. Sc. thesis, Corpus Christi State Univ., Corpus Christi, Tex. $44 \mathrm{p}$.

BURN, D. M., and G. P. SCOTT. 1988. Synopsis of available information on marine mammal-fisheries interactions in the southeastern United States: preliminary report. NMFS, SEFSC, Contribution No. CRD-87/88-26.

CADENAT, J. 1957. Observations de Cétaces, Siréniens, Chéloniens et Sauriens en 1955-1956. Bull. I'Inst. Francais d'Afrique Noire (A. Sci. Nat.), 19: 13581375.

CALDWELL, D. K. 1955. Notes on the spotted dolphin, Stenella plagiodon, and the first record of the common dolphin, Delphinus delphis, in the Gulf of Mexico. J. Mammal, 36: 467-470.

CALDWELL, D. K., and M. C. CALDWELL. 1972. The world of the bottlenosed dolphin. Biological Systems, St. Augustine, Fla. 157 p.

CATO, J. C., and F. J. PROCHASKA. 1976. Porpoise attacking hooked fish irk and injure Florida fishermen. Nat. Fish., 56: 1-4.

CLAUSEN, B., and S. ANDERSEN. 1988. Evaluation of bycatch and health status of the harbour porpoise (Phocoena phocoena) in Danish waters. Dan. Rev. Game Biol., 13: 1-20.

COE, J. M., D. B. HOLTS, and R. W. BUTLER. 1985. The "tuna-porpoise" problem: NMFS dolphin mortality reduction research, 1970-81. Mar. Fish. Rev., 46: 18-33.

CONSIGLIO, C., A. ARCANGELI, B. CRISTO, L. MARIANI, L. MARINI, and A. TORCHIO. 1992. Interactions between Tursiops truncatus and fishery [sic] along northeastern coasts of Sardinia (Italy). Abstract, Eur. Cet. Soc., 6th Annual Conference, Remo, Italy, 20-22 Feb.

CORKERON, P. J. 1990. Aspects of the behavioral ecology of inshore dolphins Tursiops truncatus and Sousa chinensis in Moreton Bay, Australia. In: The bottlenose dolphin. S. Leatherwood and R. R. Reeves (eds.), Acad. Press, San Diego, Calif., p. 285-293.

CORKERON, P. J., M. M. BRYDEN, and K. E. HEDSTROM. 1990. Feeding by bottlenose dolphins in association with trawling operations in Moreton Bay, Australia. In: The bottlenose dolphin. S. Leatherwood and R.R. Reeves (eds.), Acad. Press, San Diego, Calif., p. 329-336.

COUPERUS, A. S. 1994. Killer whales (Orcinus orca) scavenging on discards of freezer trawlers north east of the Shetland islands. Aquat. Mamm., 20: 47-51.

COUPERUS, A. S. 1997. Interactions between Dutch midwater trawlers and Atlantic white-sided dolphins (Lagenorhynchus acutus) southwest of Ireland. $J$. Northwest Atl. Fish. Sci., 22: 209-218 (this volume).

CRESPO, E. A., and J. F. CORCUERA. 1990. Interactions between marine mammals and fisheries in some fishing areas off the coast of Argentina and Uruguay. IWC Workshop on Mortality of Cetacans in Passive Fishing Nets and Traps, La Jolla, Calif, 22-25 Oct, Doc. SC/090/G2.

CRESPO, E. A., J. F. CORCUERA, and A. L. CAZORLA. 1994. Interactions between marine mammals and fisheries in some coastal fishing areas of Argentina. Rep. Int. Whal. Comm., Special Issue 15: 269-281.

CRESPO, E. A., S. N. PEDRAZA, S. L. DANS, M. K. ALONSO, L. M. REYES, N. A. GARCIA, M. COSCARELLA, and C. M. SCHIAVINI. 1997. Direct and indirect effects of the high seas fisheries on the marine mammal populations in the northern and central Patagonian coast. J. Northwest Atl. Fish. Sci., 22: 189-207 (this volume)

CURREY, D., J. LONSDALE, A. THORNTON, and P. WHITING. 1990. The global war against small cetaceans. A report by the Environmental Investigation Agency, London, U. K., 56 p.

CURREY, D., R. REEVE, A. THORNTON, and P. WHITING. 1991. The global war against small cetaceans. A second report by the Environmental Investigation 
Agency, London, U.K., 63 p.

DAVIS, L. C. 1988. An estimate of population changes of the bottlenosed dolphin, Tursiops truncatus, in Carteret County, North Carolina. J. Elisha Mitchell Sci. Soc., 104: 51-60.

DELGADO-ESTRELLA, A. MS 1991. Algunos aspectos de la ecología de poblaciones de las toninas (Tursiops truncatus Montagu, 1821) en la Laguna de Términos y Sonda de Campeche, México, Tesis, Universidad Nacional Autónoma de México.

DI NATALE, A. 1983. Distribution, frequency and biology of the common dolphin, Delphinus delphis Linneaus, in the central Mediterranean Sea. ICES Rapp. Proc.-Verb., 28: 199-200.

DI NATALE, A. 1989. Marine mammal interactions in fishery activities: the Mediterranean case. Paper presented at 1 st Int. Conf. on Mar. Mamm., Riccione, Italy, 30 Aug-2 Sept.

DI NATALE, A., and A. MANGANO. 1983. Biological distribution: new data on the sperm whale, Physeter macrocephalus L., in the central Mediterranean Sea. ICES Rapp. Proc.-Verb., 28: 183-184.

DOS SANTOS, M. E., and M. LACERDA. 1987. Preliminary observations of the bottlenose dolphin (Tursiops truncatus) in the Sado estuary (Portugal). Aquat. Mamm., 13: 65-80.

DUGUY, R. 1977. Notes on small cetaceans off the coasts of France. Rep. Int. Whal. Comm., 27: 461-462.

DUGUY, R., and E. HUSSENOT. 1982. Occasional captures of delphinids in the northeast Atlantic. Rep. Int. Whal. Comm., 32: 461-462.

EDWARDS, R. L. 1960. Observations on the behaviour of the porpoise Delphinus delphis. Science, 233: 3536.

EVERITT, R., R. BEACH, A. GEIGER, S. JEFFRIES, and S. TREACY. 1981. Marine mammal-fisheries interactions on the Columbia River and adjacent waters, 1980. Washington Game Dept., Olympia. $109 \mathrm{p}$.

FAGEN, R. M. 1981. Animal play behavior. Oxford Univ. Press, New York. 684 p.

FERTL, D. MS 1994. Occurrence, movements, and behavior of bottlenose dolphins (Tursiops truncatus) in association with the shrimp fishery in Galveston Bay, Texas. M.Sc. thesis, Texas A\&M Univ., College Station. $134 \mathrm{p}$.

FOWLER, C.W. 1982. Interactions of northern fur seals and commercial fisheries. In: Transactions of the 47th North American Wildlfe and Natural Resources Conference. The Wildlife Management Institute, Washington, DC, p. 278-292.

FULTON, G. 1976. Sounds in the night. Waters (J. Vancouver Aquar.), 1: 30-31.

GASKIN, D. E. 1984. The harbour porpoise Phocoena phocoena (L.): regional populations, status, and information on direct and indirect catches. Rep. Int. Whal. Comm., 34: 569-586.

GERRIOR, P., A. S. WILLIAMS, and D. J. CHRISTENSEN. 1994. Observations of the 1992
U.S. pelagic pair trawl fishery in the Northwest Atlantic. Mar. Fish. Rev., 56: 24-27.

GOFFMAN, O., D. KEREM, and E. SPANIER. 1995. Dolphin interactions with fishing-trawlers off the Mediterranean coast of Israel. Abstract, 11 th Biennial Conference on the Biology of Marine Mammals, Orlando, Fla., 14-18 Dec.

GOODALL, R. N. P., A. R. GALEAZZI, and A. A. LICHTER. 1988. Exploitation of small cetaceans off Argentina 1979-1986. Rep. Int. Whal. Comm., 38: $407-410$.

GOODALL, R. N. P., M. INIGUEZ, and P. SUTTON. 1990. Capture of small cetaceans in gillnets off the province of Santa Cruz, Argentina. IWC Workshop on Mortality of Cetacans in Passive Fishing Nets and Traps, La Jolla, Calif., 22-25 Oct, Doc. SC/090/ G28.

GOODWIN, B. MS 1985. Diurnal behavior patterns of Tursiops truncatus off Mobile Point, Alabama. M.Sc. thesis, San Francisco State Univ., San Francisco. $58 \mathrm{p}$.

GREEN, A., and P. J. CORKERON. 1991. An attempt to establish a feeding station for bottlenose dolphins (Tursiops truncatus) on Moreton Island, Queensland, Australia. Aquat. Mamm., 17: 125129.

GRUBER, J. MS 1981. Ecology of the Atlantic bottlenosed dolphin (Tursiops truncatus) in the Pass Cavallo area of Matagorda Bay, Texas. M.Sc. thesis, Texas A\&M Univ., College Station. 182 p.

GUINET, C. 1991. Intentional stranding apprenticeship and social play in killer whales (Orcinus orca). Can. J. Zool., 69: 2712-2716.

GUINET, C., and J. BOUVIER. 1995. Development of intentional stranding hunting techniques in killer whale (Orcinus orca) calves at Crozet Archipelago. Can. J. Zool., 73: 27-33.

GUNTER, G. 1942. Contribution to the natural history of the bottle-nose dolphin, T. truncatus (Montague), on the Texas coast, with particular reference to food habits. J. Mammal., 23: 267-276.

1944. Texas porpoises. Texas Game and Fish, 2: 11 .

1951. Consumption of shrimp by the bottlenosed dolphin. J. Mammal, 32: 465-466.

1954. Mammals of the Gulf of Mexico. U.S. Fish. Bull., 55: 543-551.

HENNINGSEN, T. MS 1991. Zur Verbreitung und Ökologie des grossen Tummlers (Tursiops truncatus) in Galveston, Texas. Diplom, ChristianAlbrechts-Univ. zu Kiel, Germany. 80 p.

HEYNING, J. E., and W. F. PERRIN. 1994. Evidence for two species of common dolphins (Genus Delphinus) from the eastern North Pacific. Contrib. Sci. Nat. Hist. Mus. LA County, Number 442, p. $1-35$.

HOGAN, T. MS 1975. Movements and behavior of the bottlenose dolphin in the Savannah River Mouth area. M. Sc. thesis, Univ. Rhode Island, Kingston. 
$42 \mathrm{p}$.

HUTCHINGS, P. 1990. Review of the effects of trawling on macrobenthic epifaunal communities. Aust. J. Mar. Freshwater Res., 41: 111-120.

INTERNATIONAL WHALING COMMMISSION (IWC). 1994. Report of the workshop on mortality of cetaceans in passive fishing nets and traps. Rep. Int. Whal. Comm., Special Issue 15: 6-71.

IVERSEN, R. T. B. MS 1975. Bottlenose dolphins stealing fish from Hawaiian fishermen's lines. Rep., SWFSC, Honolulu Lab., NMFS, NOAA, 12 p.

KENNEY, R. D., and S. D. Kraus. 1993. Right whale mortality - a correction and an update. Mar. Mamm. Sci., 9: 445-446.

KINZE, C. C. 1994. Incidental catches of harbour porpoises (Phocoena phocoena) in Danish waters, 1986-89. Rep. Int. Whal. Comm., Special Issue 15: $183-187$.

KRAUS, S. D. 1990. Rates and potential causes of mortality in North Atlantic right whales (Eubalaena glacialis). Mar. Mamm. Sci., 6: 278-291.

KREBS, J. R. 1978. Optimal foraging: decision rules for predators. In: Behavioral ecology: an evolutionary approach. J. R. Krebs and N. B. Davies (eds.), Blackwell Sci. Publ., London, p. 22-63.

KUIKEN, T., V. R. SIMPSON, C. R. ALLCHIN, P. M. BENNETT, G. A. CODD, E. A. HARRIS, G. J. HOWES, S. KENNEDY, J. K. KIRKWOOD, R. J. LAW, N. R. MERRETT, and S. PHILLIPS. 1994. Mass mortality of common dolphins (Delphinus delphis) in south west England due to incidental capture in fishing gear. Vet. Record, 134: 81-89.

LAKE, S. MS 1995. Current research: sperm whale skull. Texas Stranding Newsletter (Texas Marine Mammal Stranding Network), December: No. 7.

LEATHERWOOD, S. 1975. Some observations of feeding behavior of bottle-nosed dolphins (Tursiops truncatus) in the northern Gulf of Mexico and (Tursiops cf. T. gilli) off southern California, Baja California, and Nayarit, Mexico. Mar. Fish. Rev., 37: $10-16$.

LEATHERWOOD, S. 1994. Re-estimation of incidental cetacean catches in Sri Lanka. Rep. Int. Whal. Comm., Special Issue 15: 64-65.

LEATHERWOOD, S., D. M. McDONALD, R. W. BAIRD, and M. W. SCOTT. 1989. The false killer whale, Pseudorca crassidens: a synopsis of knowledge. San Diego, Oceans Unlimited Tech. Rep. 198 p. + Appendix 1 (114 p.).

LEATHERWOOD, S., C. B. PETERS, R. SANTERRE, M. SANTERRE, and J. T. CLARKE. 1984. Observations of cetaceans in the Northern Indian Ocean Sanctuary, November 1980 - May 1983. Rep. Int. Whal. Comm., 34: 509-520.

LEATHERWOOD, S., and M. R. PLATTER. 1975. Aerial assessment of bottlenosed dolphins off Alabama, Mississippi, and Louisiana. In: Tursiops truncatus Workshop. D.K. Odell, D.B. Siniff and G.H. Waring (eds.). Rosentiel School of Marine and Atmospheric
Science, Univ. Miami, Fla., p. 49-86.

LEATHERWOOD, S., and R. R. REEVES. 1982. Bottlenose dolphins and other toothed cetaceans. In: Wild mammals of North America. J.A. Chapman and G.A. Feldhamer (eds.). John Hopkins Univ. Press, Baltimore, Md., p. 369-414.

1983. Sierra Club handbook of whales and dolphins. Sierra Club Books, San Francisco, Calif. $302 \mathrm{p}$.

1986. Porpoises and dolphins. In: Marine mammals of eastern North Pacific and Arctic waters. D. Haley (ed.). 2nd. edn. Pacific Search Press, Seattle, Wash., p. 110-131.

LIEN, J. 1994. Entrapments of large cetaceans in passive inshore fishing gear in Newfoundland and Labrador (1979-1990). Rep. Int. Whal. Comm., Special Issue 15: $149-157$.

LINDSTEDT, I., and M. LINDSTEDT. 1989. Incidental catch of harbour porpoises Phocoena phocoena in Swedish waters in the years 1973-1988. Proceed., Eur. Cet. Soc., 3rd Annual Conference, La Rochelle, France, 24-26 Feb.

LOW, L.-L., R. E. NELSON, Jr., and R. E. NARITA. 1985. Net loss from trawl fisheries off Alaska. In: Proceedings of the workshop on the fate and impact of marine debris, 27-29 Nov. 1984, Honolulu, Hawaii. R.S. Shomura and H.O. Yoshida (eds.). U. S. Dept. of Commerce, NOAA Tech. Memo. NMFS, NOAA-TM-NMFS-SWFSC-54: 130-153.

MAF FISHERIES. 1991. Report of the seals/fisheries interactions technical working group on the Hooker's sea lion - Aucklands shelf trawl squid fishery interactions. MAF Fisheries Greta Point, Wellington, New Zealand.

MAIGRET, J. 1994. Marine mammals and fisheries along the West African coast. Rep. Int. Whal. Comm., Special Issue 15: 307-317.

MATE, B. R. 1985. Incidents of marine mammal encounters with debris and active fishing gear. In: Proceedings of the workshop on the fate and impact of marine debris, 27-29 Nov. 1984, Honolulu, Hawaii. R. S. Shomura and Y. O. Yoshida (eds.). U.S. Dept. of Commerce, NOAA Tech. Memo. NMFS, NOAA-TM-NMFS-SWFSC-54: 453-457.

MATKIN, C. O, G. ELLIS, O. VON ZIEGESAR, and R. STEINER. 1986. Killer whales and longline fisheries in Prince William Sound, Alaska 1986. Report for U.S. Dept. of Commerce, NOAA, NMFS, Natl. Mar. Mamm. Lab, Seattle, Wash., Contract 40ABNF62262. $15 \mathrm{p}$.

MATKIN, C. O., and E. L. SAULITIS. 1994. Killer whale (Orcinus orca) biology and management in Alaska. Final report for MMC contract T75135023. NTIS PB95-166203, U.S. Dept. of Commerce, Springfield, Va. $46 \mathrm{p}$.

MILLER, D. J., M. J. HERDER, and J. P. SCHOLL. MS 1983. California marine mammal-fishery interaction study, 1979-1981. Southwest Fisheries Center Admin. Rep. LJ-83-13C, 233 p. 
MITCHELL, E. D. 1975. Report of the meeting on smaller cetaceans, Montreal, April 1-11, 1974. J. Fish. Res. Board Can., 32: 889-983.

MORENO, P. 1993. Interactions of the German fisheries with small cetaceans in the North Sea: a preliminary survey. Report to World Wide Fund for Nature, Bremen.

NATIONAL MARINE FISHERIES SERVICE (NMFS). 1991. Recovery plan for the humpback whale (Megaptera novaeangliae). Prepared by the Humpback Whale Recovery Team for the Natl. Mar. Fish. Serv., Silver Springs, Md. 105 p.

1995. Environmental assessment of proposed regulations to govern interactions between marine mammals and commercial fishing operations, under section 118 of the Marine Mammal Protection Act. Natl. Mar. Fish. Serv., Off. Protect. Res., Silver Springs, Md.

NEDELEC, C., and J. PRADO. 1990. Definition and classification of fishing gear categories. FAO Fish. Tech. Pap., 222 (Rev. 1), 92 p.

NELSON, D. 1990. A review of gear and animal characteristics responsible for incidental catches of marine mammals in fishing gear. IWC Workshop on Mortality of Cetaceans in Passive Fishing Nets and Traps, La Jolla, Calif., 22-25 October, Doc. SC/090/ G48.

NIAZI, M. S. 1990. A brief on major fisheries of Pakistan and mortality of dolphins in different fishing gear. IWC Workshop on Mortality of Cetaceans in Passive Fishing Nets and Traps, La Jolla, Calif., 22-25 Oct., Doc. SC/090/G30.

NORES, C., C. PÉREZ, and J.A. PIS-MILLÁN. 1992. Cetacean by-catches in the central Cantabrian Sea: fishing gear selectivity. Proceed., Eur. Cet. Soc., 6th Annual Conference, San Remo, Italy, 20-22 Feb.

NORRIS, K. S., and J. H. PRESCOTT. 1961. Observations on Pacific cetaceans of Californian and Mexican waters. Univ. Calif. Publ. Zool., 63: 291-402.

NORTHRIDGE, S. P. 1984. World review of interactions between marine mammals and fisheries. FAO Fish. Tech. Pap., 251: 1-190.

1988. Marine mammals and fisheries: a study of conflicts with fishing gear in British waters. Wildlife Link, London.

1991. An updated world review of interactions between marine mammals and fisheries. FAO Fish. Tech. Pap., 251 (supplement 1): 1-219.

O'HARA, K., N. ATKINS, and S. IUDICELLO. 1986. Marine wildlife entanglement in North America. Report prepared for Center for Environmental Education, Washington DC. 219 p.

OVERHOLTZ, W. J., and G. T. WARING. 1991. Diet composition of pilot whales Globicephala sp. and common dolphins Delphinus delphis in the MidAtlantic Bight during Spring 1989. U.S. Fish. Bull., 89: $723-728$.

PASCOE, P. L. 1986. Size data and stomach contents of common dolphins Delphinus delphis, near Plymouth. J. Mar. Biol. Assoc., 66: 319-322.

PELLEGRIN, G., Jr. 1982. Fish discards from the southeastern United States shrimp fishery. In: International Development Research Centre. FAO. Fish by-catch-bonus from the sea. Rep. Tech. Consult. on Shrimp By-Catch Utilization, Georgetown, Guyana, p. 51-54.

PEREZ, M. A., and T. R. LOUGHLIN. 1991. Incidental catch of marine mammals by foreign and jointventure trawl vessels in the U.S. EEZ of the North Pacific, 1973-88. U.S. Dept. of Commerce, NOAA Tech. Rep., 104: 1-57.

PEREZ MACRI, G., and E. A. CRESPO. 1989. Survey of the franciscana, Pontoporia blainvillei, along the Argentine coast, with a preliminary evaluation of mortality in coastal fisheries. Biology and conservation of the river dolphins. W. F. Perrin, R. L. Brownell, Jr., K. Zhou and J. Liu, IUCN. Occasional papers of the IUCN Species Survival Commission, No. 3: 57-63.

PERRIN, W. F., N. MIYAZAKI, and T. KASUYA. 1989. A dwarf form of the spinner dolphin (Stenella longirostris) from Thailand. Mar. Mamm. Sci., 5: 213-227.

PERRIN, W. F., and S. B. REILLY. 1984. Reproductive parameters of dolphins and small whales of the family Delphinidae. Rep. Int. Whal. Comm., Special Issue 6: 97-133.

PERRIN, W. F., G. P. DONOVAN, and J. BARLOW (eds.). 1994. Gillnets and cetaceans. Rep. Int. Whal. Comm., Special Issue 15, 629 p.

PILlAi, K. S., and C. KASINATHAN. 1987. Some observations of dolphins in Mandapam Area with a note on their food. Mar. Fish. Info. Serv., India 71: $13-16$.

PRESCOTT, J. H., S. D. KRAUS, and J. R. GILBERT. 1980. East Coast/Gulf Coast cetacean and pinniped research workshop. Final report for Mar. Mamm. Commn. contract MM1533558-2. NTIS PB80160104, U.S. Dept. of Commerce, Springfield, Va. $142 \mathrm{p}$.

RAVEL, C. 1963. Damage caused by porpoises and other predatory marine animals in the Mediterranean. FAO Fish. Tech. Pap., 22: 1-7.

REIJNDERS, P. J. H., and K. LANKESTER. 1990. Status of marine mammals in the North Sea. Neth. J. Sea Res., 26: 427-435.

REYNOLDS III, J. E. 1985. Evaluation of the nature and magnitude of interactions between bottlenose dolphins, Tursiops truncatus, and fisheries and other human activities in coastal areas of the southeastern United States. A report to the Mar. Mamm. Comm., NTIS PB86-162203. U.S. Dept. of Commerce, Springfield, Va. 38 p.

RIDGWAY, S., M. REDDY, T. KAMOLNICK, D. SKARR, and C. CURRY. 1992. Calorie consumption of growing, adult, pregnant, and lactating Tursiops. Abstract, Int. Assoc. Aquat. 
Anim. Med., 23rd annual conference, Chicago, Ill., 18-22 May.

RIEDMAN, M. L., M. M. STAEDLER, J. A. ESTES, and B. HRABRICH. 1989. The transmission of individually foraging strategies from mother to offspring in sea otters (Enhydra lutris). Abstract, 8th Biennial Conf. Biol. Mar. Mamm., Pacific Grove, Calif., 7-11 Dec.

ROPELEWSKI, A. 1957. The common porpoise (Phocaena phocaena L.) as a by-catch in Polish Baltic fisheries. Prace Morskiego Instytutu Rybackiego, 9: 427-437.

SAINSBURY, K. J. 1988. The ecological basis of multispecies fisheries and management of a demersal fishery in tropical Australia. In: Fish population dynamics, 2nd edn., J. A. Gulland (ed.). John Wiley, London, p. 349-382

SCHEFFER, V. B., and J. W. SLIPP. 1948. The whales and dolphins of Washington State with a key to the cetaceans of the West Coast of North America. Amer. Midl. Natur., 39: 257-337.

SCIALABBA, N. MS 1989. World review of marine mammal entanglement in fishing gear and plastic marine debris. FAO, unpublished report. $146 \mathrm{p}$.

SEQUEIRA, M., and C. FERREIRA. 1994. Coastal fisheries and cetacean mortality in Portugal. Rep. Int. Whal. Comm., Special Issue 15: 165-181.

SHANE, S. H. MS 1977. The population biology of the Atlantic bottlenose dolphin, Tursiops truncatus, in the Aransas Pass area of Texas. M.Sc. thesis, Texas A\&M Univ., College Station. 239 p.

SHANE, S., R. WELLS, and B. WÜRSIG. 1986. Ecology, behavior and social organization of the bottlenose dolphin: a review. Mar. Mamm. Sci., 2: 34-63.

SHAUGHNESSY, P. D., and A. I. L. PAYNE. 1979. Incidental mortality of Cape fur seals during trawl fishing activities in South African waters. Fish. Bull. S. Afr., 12: 20-25.

SILVANI, L., J. RAICH, and A. AGUILAR. 1992. Bottlenose dolphins (Tursiops truncatus) interacting with local fisheries in the Balearic Islands (Spain). Proceed., Eur. Cet. Soc., 6th Annual Conference, San Remo, Italy, 20-22 Feb.

SIVASUBRAMANIAM, K. 1964. Predation of tuna longline catches in the Indian Ocean, by killerwhales and sharks. Bull. Fish. Res. Stn., Ceylon, 17: 221-236.

SKORA, K. E., I. PAWLICZKA, and M. KLINOWSKA. 1988. Observations of the harbour porpoise (Phocoena phocoena) on the Polish Baltic coast. Aquat. Mamm., 14: 113-119.

SLOOTEN, E., and S. M. DAWSON. 1988. Studies on Hector's dolphin, Cephalorhynchus hectori: a progress report. Rep. Int. Whal. Comm., Special Is- sue 9: $325-338$.

SMITH, C. R., H. KUKERT, R. A. WHEATCROFT, P. A. JUMARS, and J. W. DEMING. 1989. Vent fauna on whale remains. Nature, 341: 27-28.

TESHIMA, K., and S. OHSUMI. 1983. Note on a newborn killer whale caught alive with trawl net. J. Mammal. Soc. Japan, 9: 208-210.

TESTAVERDE, S. A. 1978. Possible capture of a harbour porpoise, Phocoena phocoena, on a tuna longline. Aquat. Mamm., 6: 90.

TYACK, P. 1986. Population biology, social behavior, and communication in whales and dolphins. Trends Ecol. Evol., 1: 144-150.

UCHIDA, R. N. 1985. The types and estimated amounts of fish net deployed in the North Pacific. In: Proceedings of the workshop on the fate and impact of marine debris, 27-29 Nov. 1984, Honolulu, Hawaii. R. S. Shomura, and H. O. Yoshida (eds.). NOAA Tech. Memo. NMFS, NOAATM-NMFS-SWFSC-54: 37-108.

VAN BREE, P. J. H., and H. NIJSSEN. 1964. On three specimens of Lagenorhynchus albirostris Gray, 1846 (Mammalia, Cetacea). Beaufortia, 11: 85-93.

VAN UTRECHT, W. L. 1978. Age and growth in Phocoena phocoena Linnaeus, 1758 (Cetacea, Odontoceti) from the North Sea. Bijdragen tot de dierkunde, 48: 16-28.

VIDAL, O. MS 1990. Population biology and exploitation of the vaquita, Phocoena sinus. IWC Sci. Comm., Doc. SC/42/SM24, 30 p.

WANG, K. R., P. M. PAYNE, and V. G. THAYER. (compilers) 1994. Coastal stock(s) of Atlantic bottlenose dolphin: status review and management. U.S. Dept. of Commerce, NOAA Tech. Memo., NMFSOPR-4. $121 \mathrm{p}$.

WARING, G. T., P. GERRIOR, P. M. PAYNE, B. C. PARRY, and J. R. NICOLAS. 1990. Incidental take of marine mamamls in foreign fishery activities off the northeast United States, 1977-88. U.S. Fish. Bull., 88: 347-360.

WASSENBERG, T. J., and B. J. HILL. 1990. Partioning of material discarded from prawn trawlers in Moreton Bay. Aust. J. Mar. Freshwater Res., 41: 27-36.

WELLS, R. S., B. G. WÜRSIG, and K. S. NORRIS. 1981. A survey of the marine mammals, including Phocoena sinus, of the upper Gulf of California. Final report for Mar. Mamm. Commn. MM 1300958-0. NTIS PB81-168791, U.S. Dept. of Commerce, Springfield, Va. 51 p.

YOUNG, N. M., S. IUDICELLO, K. EVANS, and D. BAUR. 1993. The incidental capture of marine mammals in U.S. fisheries: problems and solutions. Center for Marine Conservation, Washington, DC. 415 p. 
APPENDIX 1. Individual cetaceans documented to have been incidentally caught in trawl nets in various areas of the world.

\begin{tabular}{|c|c|c|c|c|c|}
\hline No. & Species & Time Period & \multicolumn{3}{|c|}{ No. Released } \\
\hline \multicolumn{6}{|c|}{ Bering Sea and Aleutian Islands } \\
\hline 1 & Minke whale & $1973-88$ & 2 (decomp.) & 0 & Perez and Loughlin (1991) \\
\hline 2 & Minke whale & 1989 & 1 & N/A & NMFS (1995) \\
\hline 3 & Harbor porpoise & $1973-88$ & 4 (3 dead, 1 decomp.) & 0 & Perez \& Loughlin (1991) \\
\hline 4 & Dall's porpoise & $1973-88$ & 13 (11 dead, 2 decomp.) & 0 & Perez \& Loughlin (1991) \\
\hline 5 & Dall's porpoise & 1989 & 1 & N/A & NMFS (1995) \\
\hline 6 & Dall's porpoise & 1990 & 6 & N/A & NMFS (1995) \\
\hline 7 & Dall's porpoise & 1991 & 1 & N/A & NMFS (1995) \\
\hline 8 & Dall's porpoise & 1992 & 5 & N/A & NMFS (1995) \\
\hline 9 & Dall's porpoise & 1993 & 4 & N/A & NMFS (1995) \\
\hline 10 & Risso's dolphin & $1973-88$ & 1 (decomp.) & 0 & Perez and Loughlin (1991) \\
\hline 11 & Killer whale & 1982 & 1 calf & 1 calf & Teshima and Ohsumi (1983) \\
\hline 12 & Killer whale & $1973-88$ & 4 ( 1 dead, 1 alive, 2 decomp.) & N/A & Perez and Loughlin (1991) \\
\hline 13 & Killer whale & 1991 & 1 & 0 & $\begin{array}{l}\text { NMFS (1995); Matkin and } \\
\text { Saulitis (1994) }\end{array}$ \\
\hline 14 & Killer whale & 1992 & 1 & N/A & NMFS (1995) \\
\hline 15 & Killer whale & 1993 & 1 & N/A & NMFS (1995) \\
\hline 16 & Unid. cetacean & $1973-88$ & 25 (7 dead, 18 decomp.) & 0 & Perez and Loughlin (1991) \\
\hline 17 & Unid. cetacean & 1990 & 1 & N/A & NMFS (1995) \\
\hline 18 & Unid. cetacean & 1991 & 1 & N/A & NMFS (1995) \\
\hline 19 & Unid. cetacean & 1992 & 1 & N/A & NMFS (1995) \\
\hline 20 & Unid. cetacean & 1993 & 1 & N/A & NMFS (1995) \\
\hline
\end{tabular}

\section{British Columbia}

\begin{tabular}{llllll}
21 & Dall's porpoise & 1990 & 1 & 0 & Baird et al. (MS 1991) \\
\hline & & \multicolumn{3}{c}{ Gulf of Alaska } \\
22 & Dall's porpoise & $1973-88$ & $2(1 \mathrm{dead}, 1$ alive) & N/A & Perez and Loughlin (1991) \\
23 & Dall's porpoise & 1993 & 1 N/A & NMFS (1995) \\
24 & Killer whale & $1973-88$ & 1 dead & 0 & Perez and Loughlin (1991) \\
25 & Unid. cetacean & $1973-88$ & 2 dead & 0 & Perez and Loughlin (1991) \\
\hline
\end{tabular}

\section{Alaska}

$\begin{array}{llllll}26 & \text { Harbor porpoise } & 1941 & 1 \text { (dredged by trawler) } & 0 & \text { Scheffer and Slipp (1948) } \\ 27 & \text { Harbor porpoise } & 1986-88 & 3 & \text { N/A } & \text { Barlow et al. (1994) } \\ 28 & \text { Dall's porpoise } & 1986-88 & 20 & \text { N/A } & \text { Barlow } \text { et al. }(1994) \\ 29 & \text { Dall's porpoise } & 1989 & 1 & \text { N/A } & \text { Barlow } \text { et al. }(1994) \\ 30 & \begin{array}{l}\text { Pacific white- } \\ \text { sided dolphin }\end{array} & \text { N/A } & 3 & \text { N/A } & \text { Barlow } \text { et al. }(1994) \\ 31 & \text { Killer whale } & \text { 1986-88 } & 2 & & \\ 32 & \text { Unid. cetacean } & \text { N/A } & 18 & \text { N/A } & \text { Barlow et al. }(1994) \\ & & & \text { N/A } & \text { Barlow } \text { et al. }(1994)\end{array}$

\section{West Coast of United States}

\begin{tabular}{|c|c|c|c|c|}
\hline Dall's porpoise & $1973-88$ & 9 ( 8 dead, 1 alive $)$ & N/A & Perez and Loughlin (1991) \\
\hline Dall's porpoise & 1989 & 1 & N/A & NMFS (1995) \\
\hline Dall's porpoise & 1990 & 3 & N/A & NMFS (1995) \\
\hline Dall's porpoise & 1992 & 1 & N/A & NMFS (1995) \\
\hline
\end{tabular}




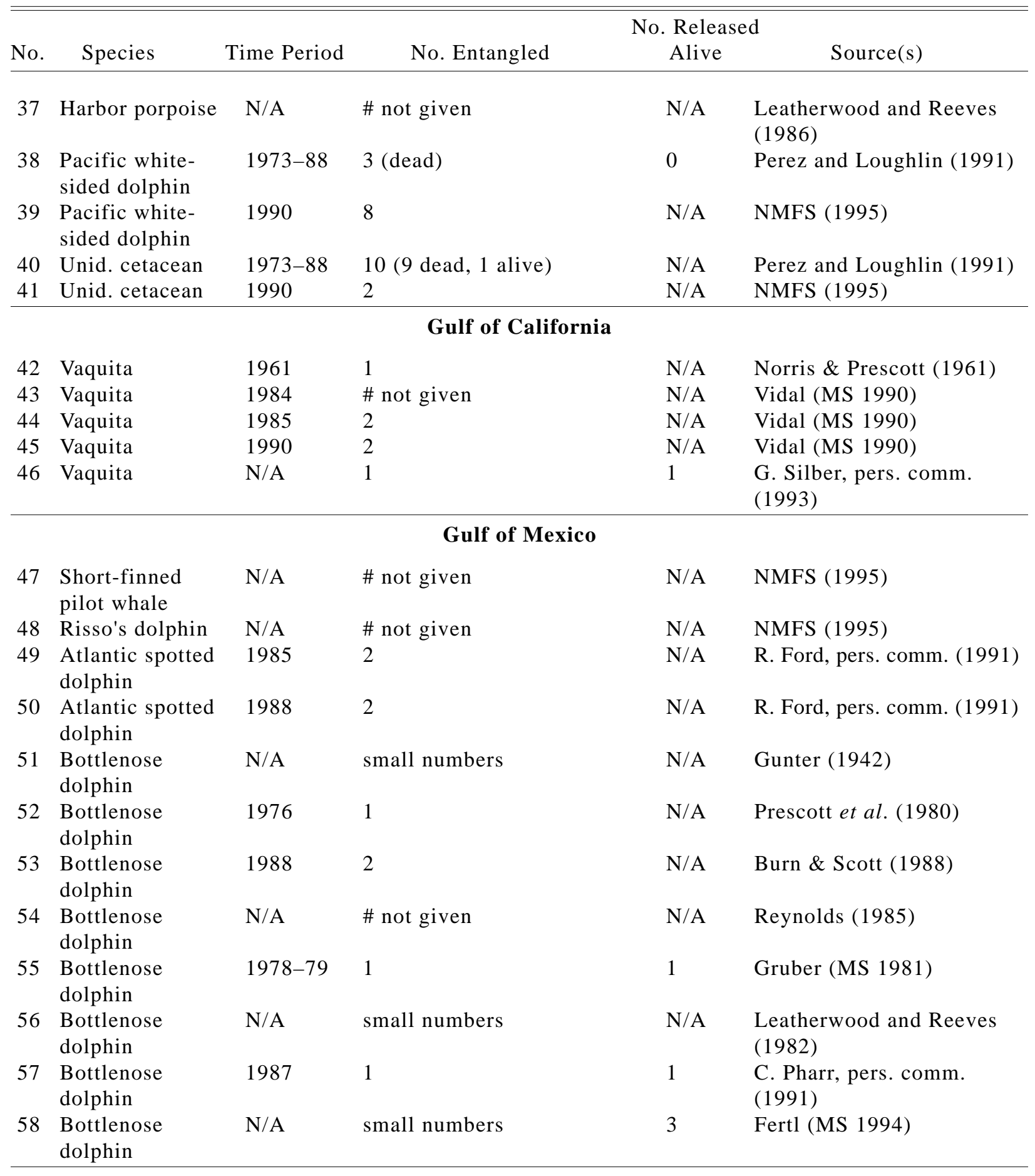

\section{Southeastern United States}

$\begin{array}{llllll}59 & \begin{array}{l}\text { Bottlenose } \\ \text { dolphin }\end{array} & \text { N/A } & 1 & \text { N/A } & \text { Wang et al. (1994) } \\ 60 & \begin{array}{l}\text { Bottlenose } \\ \text { dolphin }\end{array} & \text { N/A } & \text { small numbers } & \text { N/A } & \text { Reynolds (1985) }\end{array}$




\begin{tabular}{|c|c|c|c|c|c|}
\hline No. & Species & Time Period & \multicolumn{3}{|c|}{$\begin{array}{c}\text { No. Released } \\
\text { Alive }\end{array}$} \\
\hline \multicolumn{6}{|c|}{ Northeastern United Atates/Atlantic Ocean } \\
\hline 61 & Humpback whale & 1986 & 2 (1 alive, 1 dead $)$ & N/A & O'Hara et al. (1986) \\
\hline 62 & Harbor porpoise & 1977 & 1 (decomp.) & 0 & Testaverde (1978) \\
\hline 63 & Harbor porpoise & 1982 & 1 & N/A & O'Hara et al. (1986) \\
\hline 64 & Common dolphin & $1977-83$ & 8 & N/A & Waring et al. (1990) \\
\hline 65 & Common dolphin & 1983 & 1 (alive) & N/A & O'Hara et al. (1986) \\
\hline 66 & Common dolphin & 1984 & 3 & N/A & Waring et al. (1990) \\
\hline 67 & Common dolphin & 1985 & 66 & N/A & Waring et al. (1990) \\
\hline 68 & Common dolphin & 1986 & 76 & N/A & Waring et al. (1990) \\
\hline 69 & Common dolphin & 1987 & 19 & N/A & Waring et al. (1990) \\
\hline 70 & Common dolphin & 1988 & 31 & N/A & Waring et al. (1990) \\
\hline 71 & Common dolphin & 1989 & 4 & 0 & Overholtz and Waring (1991) \\
\hline 72 & Common dolphin & 1990 & 11 & N/A & NMFS (1995) \\
\hline 73 & Common dolphin & 1991 & 2 & N/A & NMFS (1995) \\
\hline 74 & Common dolphin & 1992 & 3 & 0 & Gerrior et al. (1994) \\
\hline 75 & Common dolphin & 1993 & 6 & N/A & NMFS (1995) \\
\hline 76 & Pilot whale & $1977-83$ & 35 & N/A & Waring et al. (1990) \\
\hline 77 & Pilot whale & 1984 & 2 & N/A & Waring et al. (1990) \\
\hline 78 & Pilot whale & 1985 & 47 & N/A & Waring et al. (1990) \\
\hline 79 & Pilot whale & 1986 & 20 & 2 & Waring et al. (1990) \\
\hline 80 & Pilot whale & 1987 & 26 & 1 & Waring et al. (1990) \\
\hline 81 & Pilot whale & 1988 & 142 & 3 & Waring et al. (1990) \\
\hline 82 & Pilot whale & 1989 & 5 & 0 & Overholtz and Waring (1991) \\
\hline 83 & Pilot whale & 1990 & 1 & N/A & NMFS (1995) \\
\hline 84 & Pilot whale & 1990 & 107 & N/A & Young et al. (1993) \\
\hline 85 & Pilot whale & 1991 & 13 & N/A & Young et al. (1993) \\
\hline 86 & Pilot whale & 1992 & 12 & N/A & NMFS (1995) \\
\hline 87 & Risso's dolphin & 1985 & 1 & N/A & Waring et al. (1990) \\
\hline 88 & Risso's dolphin & 1986 & 1 & N/A & Waring et al. (1990) \\
\hline 89 & Risso's dolphin & 1987 & 1 & N/A & Waring et al. (1990) \\
\hline 90 & Risso's dolphin & 1992 & 1 & 0 & Gerrior et al. (1994) \\
\hline 91 & $\begin{array}{l}\text { Atlantic white- } \\
\text { sided dolphin }\end{array}$ & 1990 & 4 & N/A & Young et al. (1993) \\
\hline 92 & $\begin{array}{l}\text { Atlantic white- } \\
\text { sided dolphin }\end{array}$ & 1990 & 10 & N/A & NMFS (1995) \\
\hline 93 & $\begin{array}{l}\text { Atlantic white- } \\
\text { sided dolphin }\end{array}$ & 1991 & 1 & N/A & Young et al. (1993) \\
\hline 94 & $\begin{array}{l}\text { Atlantic white- } \\
\text { sided dolphin }\end{array}$ & 1991 & 7 & N/A & NMFS (1995) \\
\hline 95 & Striped dolphin & 1991 & 2 & N/A & NMFS (1995) \\
\hline 96 & Bottlenose dolphin & n $1977-83$ & 2 & N/A & Waring et al. (1990) \\
\hline 97 & Bottlenose dolphin & n 1984 & 1 & N/A & Waring et al. (1990) \\
\hline 98 & Bottlenose dolphin & n 1985 & 3 & N/A & Waring et al. (1990) \\
\hline 99 & Bottlenose dolphin & n 1988 & 2 & N/A & Waring et al. (1990) \\
\hline 100 & Bottlenose dolphin & n 1991 & 1 & N/A & NMFS (1995) \\
\hline 101 & Bottlenose dolphin & n 1992 & 4 & N/A & Gerrior et al. (1994) \\
\hline 102 & Bottlenose dolphin & n 1993 & 17 & N/A & NMFS (1995) \\
\hline
\end{tabular}




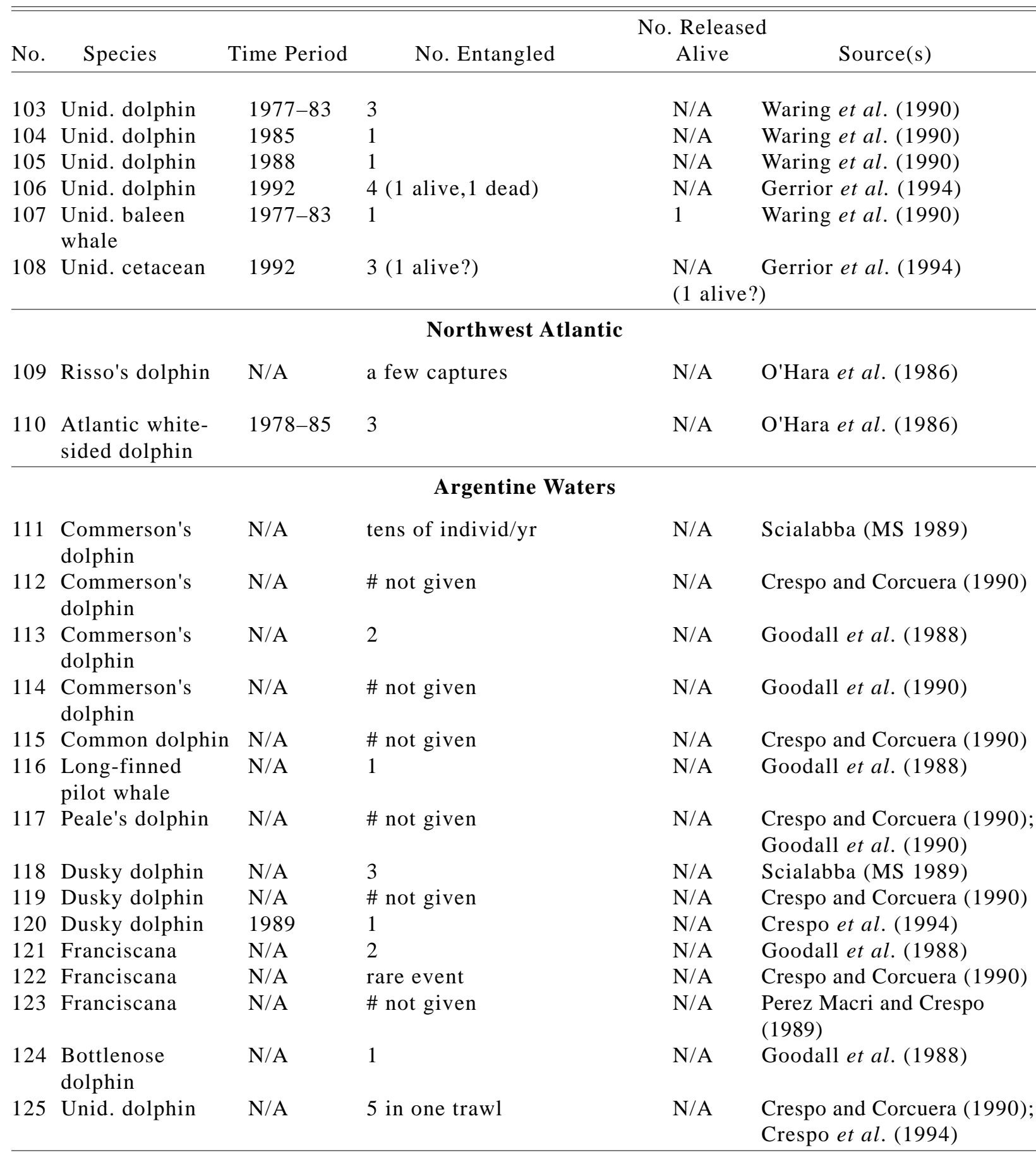

\section{Northeast Atlantic}

126 Harbor porpoise $1980-81 \quad 28$

127 Harbor porpoise $\quad-\quad 3$

128 Harbor porpoise 1973-87 21
N/A Andersen and Clausen (MS 1983)

N/A Anonymous (1988b)

N/A Lindstedt and Lindstedt (1989) 


\begin{tabular}{|c|c|c|c|c|c|}
\hline No. & Species & Time Period & No. Entangled & $\begin{array}{l}\text { No. Released } \\
\text { Alive }\end{array}$ & Source(s) \\
\hline 129 & Harbor porpoise & $1986-89$ & 4 & N/A & Kinze (1994) \\
\hline 130 & Common dolphin & $1971-81$ & 15 & N/A & Duguy and Hussenot (1982) \\
\hline 131 & Common dolphin & $1971-76$ & 1 & N/A & Duguy (1977) \\
\hline 132 & $\begin{array}{l}\text { Long-finned } \\
\text { pilot whale }\end{array}$ & $1971-76$ & 1 & N/A & Duguy (1977) \\
\hline 133 & $\begin{array}{l}\text { Long-finned } \\
\text { pilot whale }\end{array}$ & $1971-81$ & 3 & N/A & Duguy and Hussenot (1982) \\
\hline 134 & $\begin{array}{l}\text { Long-finned } \\
\text { pilot whale }\end{array}$ & - & possible 1 record & N/A & Northridge (1988) \\
\hline 135 & Risso's dolphin & - & occasionally caught & N/A & Northridge (1984) \\
\hline 136 & Striped dolphin & - & occasionally caught & N/A & Northridge (1984) \\
\hline 137 & Striped dolphin & $1971-76$ & 1 & N/A & Duguy (1977) \\
\hline 138 & Bottlenose dolphin & n 1971-76 & 2 & N/A & Duguy (1977) \\
\hline 139 & Bottlenose dolphin & n 1977-81 & 3 & N/A & Duguy and Hussenot (1982) \\
\hline 140 & Bottlenose dolphin & $\mathrm{n}-$ & 1 & N/A & Anonymous (1988b) \\
\hline
\end{tabular}

Baltic Sea

141 Harbor porpoise $1952 \quad 1$

142 Harbor porpoise N/A 2

143 Harbor porpoise 1987/90
N/A Ropelewski (1957)

N/A Skora et al. (1988)

N/A Benke et al. (1991)

\section{North Sea}

\begin{tabular}{|c|c|c|c|c|c|}
\hline 144 & Harbor porpoise & - & several tens/yr & N/A & Currey et al. (1990) \\
\hline 145 & Harbor porpoise & $1963-82$ & 18 & N/A & Gaskin (1984) \\
\hline 146 & Harbor porpoise & $1987-88$ & 7 & N/A & Anonymous (1989a) \\
\hline 147 & Harbor porpoise & - & few & N/A & Mitchell (1975) \\
\hline 148 & Harbor porpoise & 1992 & 137 & N/A & Moreno (1993) \\
\hline 149 & Harbor porpoise & - & regularly caught & N/A & $\begin{array}{l}\text { Reijnders and Lankester } \\
(1990)\end{array}$ \\
\hline 150 & Common dolphin & - & regularly caught & N/A & $\begin{array}{l}\text { Reijnders and Lankester } \\
(1990)\end{array}$ \\
\hline 151 & Pilot whale & - & regularly caught & N/A & $\begin{array}{l}\text { Reijnders and Lankester } \\
(1990)\end{array}$ \\
\hline 152 & Pilot whale & 1994 & 3 (dead) in 1 haul & 0 & $\begin{array}{l}\text { N. Lowry, pers. comm. } \\
\text { (1994) }\end{array}$ \\
\hline 153 & Risso's dolphin & - & not given & N/A & $\begin{array}{l}\text { Reijnders and Lankester } \\
\text { (1990) }\end{array}$ \\
\hline 154 & $\begin{array}{l}\text { White-beaked } \\
\text { dolphin }\end{array}$ & - & few & N/A & $\begin{array}{l}\text { Leatherwood and Reeves } \\
\text { (1983) }\end{array}$ \\
\hline 155 & $\begin{array}{l}\text { White-beaked } \\
\text { dolphin }\end{array}$ & 1958 & 1 & N/A & $\begin{array}{l}\text { van Bree and Nijssen } \\
\text { (1964) }\end{array}$ \\
\hline 156 & Bottlenose dolphin & - & \# not given & N/A & Currey et al. (1990) \\
\hline 157 & Bottlenose dolphin & - & few & N/A & Mitchell (1975) \\
\hline
\end{tabular}




\begin{tabular}{|c|c|c|c|c|c|}
\hline \multirow[t]{2}{*}{ No. } & Species & Time Period & \multicolumn{3}{|c|}{$\begin{array}{l}\text { No. Released } \\
\text { Alive }\end{array}$} \\
\hline & \multicolumn{5}{|c|}{ Mid-Atlantic Bight } \\
\hline 158 & $\begin{array}{l}\text { Bottlenose } \\
\text { dolphin }\end{array}$ & N/A & 3 in 8 years & N/A & Northridge (1991) \\
\hline \multicolumn{6}{|c|}{ Scotland } \\
\hline 159 & Harbor porpoise & $1988-89$ & $20+$ & N/A & Northridge (1991) \\
\hline \multicolumn{6}{|c|}{ Britain } \\
\hline 160 & Harbor porpoise & N/A & \# not given & N/A & Northridge (1991) \\
\hline 161 & Harbor porpoise & N/A & 1 & N/A & Northridge (1988) \\
\hline 162 & Harbor porpoise & 1989 & 2 & N/A & Anonymous (1990c) \\
\hline 163 & Common dolphin & 1982 & 5 (3 alive, 2 dead $)$ & 3 & Pascoe (1986) \\
\hline 164 & Common dolphin & $\mathrm{N} / \mathrm{A}$ & \# not given & N/A & Couperus (1994) \\
\hline 165 & Pilot whale & 1986 & towed in trawl & N/A & Northridge (1988) \\
\hline 166 & $\begin{array}{l}\text { Long-finned } \\
\text { pilot whale }\end{array}$ & N/A & \# not given & N/A & Couperus (1994) \\
\hline 167 & $\begin{array}{l}\text { Atlantic white- } \\
\text { sided dolphin }\end{array}$ & N/A & \# not given & N/A & Couperus (1994) \\
\hline 168 & $\begin{array}{l}\text { White-beaked } \\
\text { dolphin }\end{array}$ & 1986,1987 & \# not given & N/A & Northridge (1988) \\
\hline 169 & $\begin{array}{l}\text { White-beaked } \\
\text { dolphin }\end{array}$ & N/A & \# not given & N/A & Couperus (1994) \\
\hline 170 & Unid. porpoise & N/A & $\begin{array}{l}\text { entangled at least } 6 \text {, one } \\
\text { drowned in net }\end{array}$ & N/A & Northridge (1988) \\
\hline 171 & Unid. porpoise & N/A & 3 & N/A & Northridge (1988) \\
\hline 172 & Unid. whale & 1986 & 1 & N/A & Northridge (1988) \\
\hline \multicolumn{6}{|c|}{ Eastern Central Atlantic } \\
\hline 173 & Common dolphin & N/A & \# not given & N/A & Scialabba (MS 1989) \\
\hline 174 & $\begin{array}{l}\text { Bottlenose } \\
\text { dolphin }\end{array}$ & N/A & \# not given & N/A & Scialabba (MS 1989) \\
\hline \multicolumn{6}{|c|}{ Bay of Biscay } \\
\hline 175 & $\begin{array}{l}\text { Long-finned } \\
\text { pilot whale }\end{array}$ & N/A & \# not given & N/A & Gerrior et al. (1994) \\
\hline \multicolumn{6}{|c|}{ Mediterranean } \\
\hline 176 & Common dolphin & N/A & 1 & N/A & Di Natale (1983) \\
\hline 177 & Common dolphin & N/A & not given & N/A & Di Natale (1989) \\
\hline 178 & Striped dolphin & N/A & not given & N/A & Di Natale (1989) \\
\hline 179 & $\begin{array}{l}\text { Bottlenose } \\
\text { dolphin }\end{array}$ & N/A & 3 & N/A & Duguy and Hussenot (1982) \\
\hline 180 & $\begin{array}{l}\text { Bottlenose } \\
\text { dolphin }\end{array}$ & N/A & $\begin{array}{l}\text { incidental catches said to } \\
\text { be high, although some } \\
\text { dolphins reported to be freed }\end{array}$ & N/A & Currey et al. (1990) \\
\hline 181 & $\begin{array}{l}\text { Bottlenose } \\
\text { dolphin }\end{array}$ & N/A & not given & N/A & Di Natale (1989) \\
\hline
\end{tabular}




\begin{tabular}{|c|c|c|c|c|c|c|}
\hline No. & Species & Time Period & \multicolumn{4}{|c|}{$\begin{array}{l}\text { No. Released } \\
\text { Alive }\end{array}$} \\
\hline 182 & $\begin{array}{l}\text { Bottlenose } \\
\text { dolphin }\end{array}$ & N/A & 1 & & N/A & Silvani et al. (1992) \\
\hline 183 & Sperm whale & N/A & 3 & & N/A & $\begin{array}{l}\text { Di Natale and Mangano } \\
\text { (1983) }\end{array}$ \\
\hline 184 & Sperm whale & N/A & 1 & & N/A & Di Natale (1989) \\
\hline \multicolumn{7}{|c|}{ Portugal } \\
\hline 185 & Harbor porpoise & 1977-91 & 1 & & N/A & Sequeira and Ferreira (1994) \\
\hline 186 & Common dolphin & $1977-91$ & 18 & & N/A & Sequeira and Ferreira (1994) \\
\hline \multicolumn{7}{|c|}{ Central Cantabrian Sea } \\
\hline 187 & Harbor porpoise & $1977-91$ & 1 & & N/A & Nores et al. (1992) \\
\hline 188 & Common dolphin & $1977-91$ & 1 & & N/A & Nores et al. (1992) \\
\hline 189 & $\begin{array}{l}\text { Long-finned } \\
\text { pilot whale }\end{array}$ & 1977-91 & 1 & & N/A & Nores et al. (1992) \\
\hline
\end{tabular}

\section{Northwest Africa}

190 Common dolphin N/A

191 Common dolphin N/A 192 Common dolphin 1980

\# not given

large numbers

'6-22' dolphins per haul' at night for one trawler. 12 trawlers in area also caught dolphins, exact number unknown. An estimated minimum of 500-1 000 common dolphins and Stenella spp. are caught per year.

\begin{tabular}{|c|c|c|c|c|c|}
\hline & Со⿴囗十⺝ & 1700 & \multicolumn{2}{|c|}{$\begin{array}{l}\text { at night for one trawler. } 12 \\
\text { trawlers in area also caught dolphins, } \\
\text { exact number unknown. An estimated } \\
\text { minimum of } 500-1000 \text { common } \\
\text { dolphins and Stenella spp. are caught } \\
\text { per year. }\end{array}$} & (ד) \\
\hline \multicolumn{6}{|c|}{ South and Southwest Africa } \\
\hline 193 & $\begin{array}{l}\text { Heaviside's } \\
\text { dolphin }\end{array}$ & $1978-79$ & 2 & N/A & Anonymous (1979) \\
\hline 194 & $\begin{array}{l}\text { Heaviside's } \\
\text { dolphin }\end{array}$ & $1978-79$ & small numbers & N/A & Northridge (1984) \\
\hline 195 & $\begin{array}{l}\text { Heaviside's } \\
\text { dolphin }\end{array}$ & 1977 & 1 & N/A & P. Best, pers. comm. (1992) \\
\hline 196 & $\begin{array}{l}\text { Heaviside's } \\
\text { dolphin }\end{array}$ & 1990 & 1 & N/A & P. Best, pers. comm. (1992) \\
\hline 197 & $\begin{array}{l}\text { Common } \\
\text { dolphin }\end{array}$ & N/A & small numbers & N/A & Northridge (1984) \\
\hline 198 & $\begin{array}{l}\text { Common } \\
\text { dolphin }\end{array}$ & 1983 & 5 & N/A & P. Best, pers. comm. (1992) \\
\hline 199 & $\begin{array}{l}\text { Common } \\
\text { dolphin }\end{array}$ & N/A & 2 young & N/A & $\begin{array}{l}\text { V. Cockcroft, pers. comm. } \\
\text { (1992) }\end{array}$ \\
\hline 200 & Risso's dolphin & 1986 & 1 & N/A & P. Best, pers. comm. (1992) \\
\hline 201 & Dusky dolphin & N/A & small numbers & N/A & Northridge (1984) \\
\hline 202 & Dusky dolphin & 1988 & 4 & N/A & P. Best, pers. comm. (1992) \\
\hline 203 & Dusky dolphin & 1989 & 6 & N/A & P. Best, pers. comm. (1992) \\
\hline 204 & Dusky dolphin & 1990 & 1 & N/A & P. Best, pers. comm. (1992) \\
\hline
\end{tabular}

N/A Northridge (1984)

N/A Currey et al. (1990)

N/A Maigret (1994) 


\begin{tabular}{|c|c|c|c|c|c|}
\hline No. & Species & Time Period & No. Entangled & No. Released & Source(s) \\
\hline \multicolumn{6}{|c|}{ East Africa } \\
\hline 205 & Unid. dolphin & N/A & large number & N/A & Currey et al. (1991) \\
\hline \multicolumn{6}{|c|}{ Pakisan } \\
\hline 206 & Finless porpoise & 1989 & 2 young & N/A & Niazi (1990) \\
\hline \multicolumn{6}{|c|}{ India (Gulf of Mannar) } \\
\hline 207 & $\begin{array}{l}\text { Bottlenose } \\
\text { dolphin }\end{array}$ & $1980-82$ & 3 & 0 & Pillai \& Kasinathan (1987) \\
\hline
\end{tabular}

Thailand

208 Spinner dolphin 1970-71 $10 \quad$ N/A Perrin et al. (1989)

\section{China (Hong Kong)}

209 Finless porpoise 1987
T. Jefferson, pers. comm (1995)

\begin{tabular}{|c|c|c|c|c|c|}
\hline \multicolumn{6}{|c|}{ New Zealand } \\
\hline 210 & Hector's dolphin & 1970 's & 7 & N/A & Baker (1978) \\
\hline 211 & Hector's dolphin & N/A & occasionally & N/A & $\begin{array}{l}\text { Anonymous (1981); } \\
\text { Scialabba (MS 1989); } \\
\text { Slooten and Dawson (1988) }\end{array}$ \\
\hline 212 & Hector's dolphin & 1988 & 5 & N/A & Anonymous (1990b) \\
\hline 213 & Common dolphin & N/A & a few & N/A & Mitchell (1975) \\
\hline 214 & Common dolphin & 1978 & 10 & 4 & Anonymous (1981) \\
\hline 215 & Common dolphin & 1979 & 23 & 2 & Anonymous (1981) \\
\hline 216 & Common dolphin & N/A & occasionally & N/A & Slooten and Dawson (1988) \\
\hline 217 & Common dolphin & 1980 & 1 & N/A & Anonymous (1982) \\
\hline 218 & Common dolphin & since & 2 & N/A & Anonymous (1988a) \\
\hline \multicolumn{6}{|c|}{ April 1986} \\
\hline 219 & Common dolphin & 1987 & 1 & N/A & Anonymous (1989b) \\
\hline 220 & Common dolphin & 1988 & 1 & N/A & Anonymous (1990b) \\
\hline 221 & Common dolphin & 1989 & 2 (adult+calf) & N/A & Anonymous (1990b) \\
\hline 222 & Common dolphin & $\begin{array}{l}1989-90 \\
1993-94\end{array}$ & 69 & N/A & Baird (1995) \\
\hline 223 & Common dolphin & 1990 & $34-35$ & N/A & Anonymous (1991b) \\
\hline 224 & Common dolphin & 1995 & 21 & N/A & $\begin{array}{l}\text { R. Mattlin, pers. comm. } \\
\text { (1995) }\end{array}$ \\
\hline 225 & Pilot whale & N/A & 1 & N/A & $\begin{array}{l}\text { R. Mattlin, pers. comm. } \\
\text { (1995) }\end{array}$ \\
\hline 226 & Dusky dolphin & $1986-88$ & 2 & N/A & Anonymous (1988a) \\
\hline 227 & Dusky dolphin & 1988 & 1 & N/A & Anonymous (1988a) \\
\hline
\end{tabular}




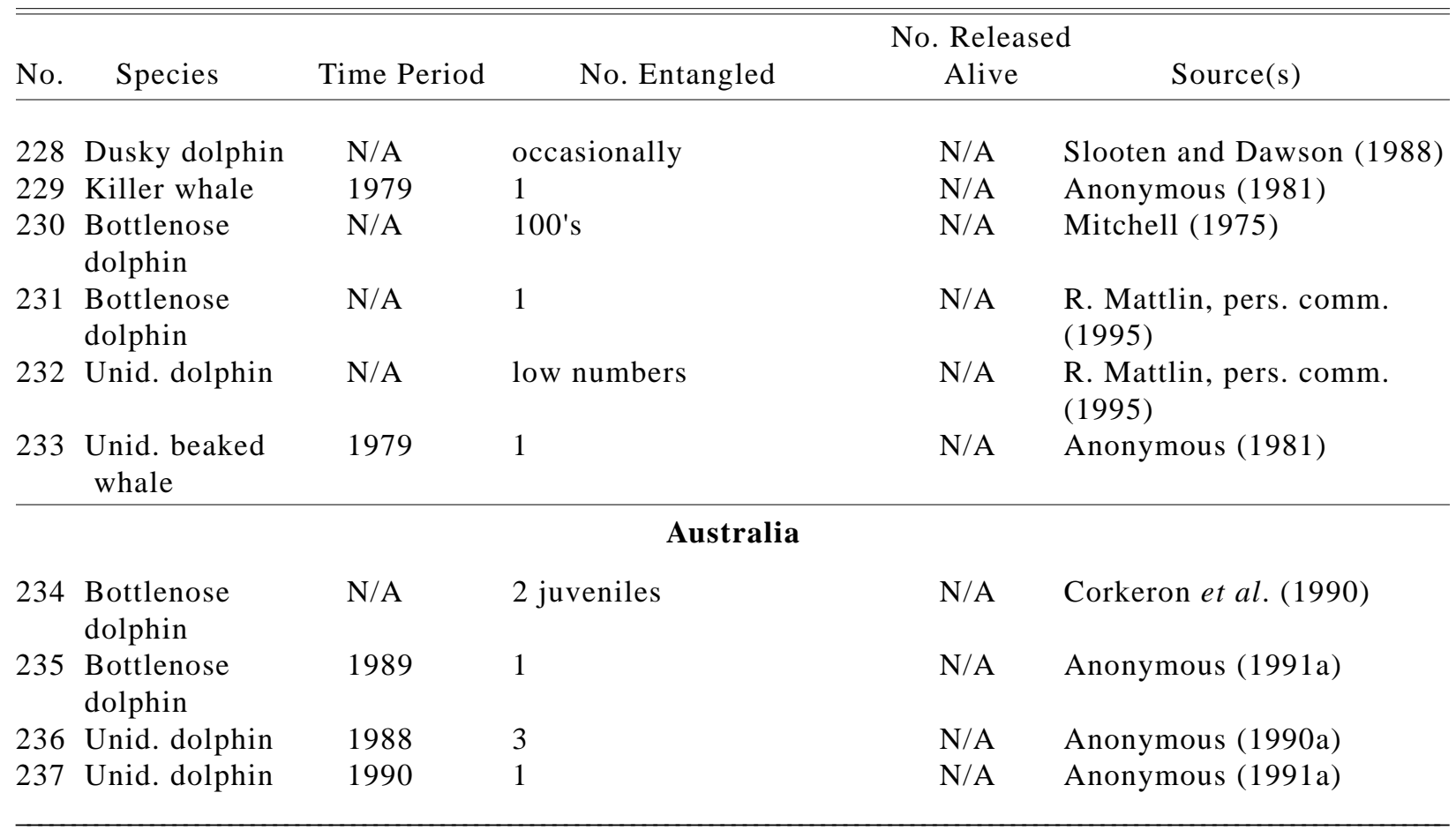

\section{Sources for personal communications}

P. Best, Whale Unit c/o South African Museum, P. O. Box 61, Cape Town 8000, South Africa

V. Cockcroft, Port Elizabeth Museum, P. O. Box 13147, Humewood 6013 South Africa

R. Ford, National Marine Fisheries Service, P. O. Drawer 1207, Pascagoula, MS 39568, USA

T. Jefferson, Ocean Park Conservation Foundation, Ocean Park Aquarium, Aberdeen, Hong Kong

N. Lowry, Danish Institute for Fisheries Technology and Aquaculture, The North Sea Centre, P. O. Box 59, DK-9850 Hirtshals, Denmark

R. Mattlin, MAF Fisheries, Greta Point, P. O. Box 297, Wellington, New Zealand

C. Pharr, National Marine Fisheries Service, P. O. Drawer 1207, Pascagoula, MS 39568, USA

G. Silber, Marine Mammal Commission, 1825 Connecticut Avenue, NW, Washington, DC 20009, USA 
APPENDIX 2. Cetacean species for which there are reports of incidental catches in trawl nets (Record numbers correspond to entries in Appendix 1.)

\begin{tabular}{|c|c|}
\hline Species & Record Number(s) \\
\hline Minke whale (Balaenoptera acutorostrata) & 1,2 \\
\hline Humpback whale (Megaptera novaeangliae) & 61 \\
\hline Finless porpoise (Neophocaena phocaenoides) & 206,209 \\
\hline Dall's porpoise (Phocoenoides dalli) & $4-9,21-23,28-29,33-36$ \\
\hline Harbor porpoise (Phocoena phocoena) & $\begin{array}{l}3,26-27,37,62-63,126-129,141-149 \\
159-162,185,187\end{array}$ \\
\hline Vaquita (Phocoena sinus) & $42-46$ \\
\hline Sperm whale (Physeter macrocephalus) & $183-184$ \\
\hline Commerson's dolphin (Cephalorhynchus commersonii) & $111-114$ \\
\hline Heaviside's dolphin (Cephalorhynchus heavisidii) & $193-196$ \\
\hline Hector's dolphin (Cephalorhynchus hectori) & $210-212$ \\
\hline Common dolphin (Delphinus spp.) & $\begin{array}{l}64-75,115,130-131,150,163-164,173 \\
176-177,186,188,190-192,197-199, \\
213-224\end{array}$ \\
\hline Short-finned pilot whale (Globicephala macrorhynchus) & 47 \\
\hline Long-finned pilot whale (Globicephala melas) & $116,132-134,166,175,189$ \\
\hline Unidentified pilot whale species (Globicephala spp.) & $76-86,151-152,165,225$ \\
\hline Risso's dolphin (Grampus griseus) & $10,48,87-90,109,135,153,200$ \\
\hline Atlantic white-sided dolphin (Lagenorhynchus acutus) & $91-94,110,167$ \\
\hline White-beaked dolphin (Lagenorhynchus albirostris) & $154-155,168-169$ \\
\hline Peale's dolphin (Lagenorhynchus australis) & 117 \\
\hline Pacific white-sided dolphin (Lagenorhynchus obliquidens) & $30,38-39$ \\
\hline Dusky dolphin (Lagenorhynchus obscurus) & $118-120,201-204,226-228$ \\
\hline Killer whale (Orcinus orca) & $11-15,24,31,229$ \\
\hline Striped dolphin (Stenella coeruleoalba) & $95,136-137,178$ \\
\hline Atlantic spotted dolphin (Stenella frontalis) & $49-50$ \\
\hline Spinner dolphin (Stenella longirostris) & 208 \\
\hline Bottlenose dolphin (Tursiops truncatus) & $\begin{array}{c}51-60,96-102,124,138-140,156-158 \\
174,179-182,207,230-231,234-235\end{array}$ \\
\hline Franciscana (Pontoporia blainvillei) & $121-123$ \\
\hline Unid. cetacean species & $16-20,25,32,40-41,108$ \\
\hline Unidentified baleen whale & 107 \\
\hline Unididentified dolphin species & $103-106,125,205,232,236-237$ \\
\hline Unidentified beaked whale & 233 \\
\hline Unidentified porpoise & $170-171$ \\
\hline Unidentified whale & 172 \\
\hline
\end{tabular}


APPENDIX 3. Accounts of cetaceans feeding in association with trawls, reported geographically.

\begin{tabular}{|c|c|c|}
\hline Species & Interaction & Source(s) \\
\hline \multicolumn{3}{|c|}{ Bering Sea } \\
\hline Killer whale & Seen following nets when trawling began. & Teshima and Ohsumi (1983) \\
\hline Killer whale & $\begin{array}{l}\text { Seemed attracted to winching sounds. Positioned } \\
\text { themselves along the sides of trawlers to feed on } \\
\text { trash fish, and offal. Jostled for positions while } \\
\text { feeding was also noted. }\end{array}$ & $\begin{array}{l}\text { J. Heimlich-Boran, } \\
\text { pers. comm. (1991) }\end{array}$ \\
\hline
\end{tabular}

\section{West Coast of United States}

Common dolphin Feed on specimens that had escaped from the net. Edwards (1960) The fish were disabled and floating belly up.

\section{Gulf of California}

\begin{tabular}{lll}
$\begin{array}{l}\text { Bottlenose } \\
\text { dolphin }\end{array}$ & $\begin{array}{l}\text { Seen associated with shrimpers. Observed to feed } \\
\text { on trash fish. Dolphins attracted to engines shutting } \\
\text { down, signifying culling. }\end{array}$ & Norris \& Prescott (1961) \\
$\begin{array}{l}\text { Bottlenose } \\
\text { dolphin }\end{array}$ & Observed feeding in mudboil behind shrimpers. & Leatherwood (1975) \\
$\begin{array}{l}\text { Bottlenose } \\
\text { dolphin }\end{array}$ & $\begin{array}{l}\text { Habitually followed trawlers with net down } \\
\text { (19\% of sightings). }\end{array}$ & Wells et al. (1981) \\
\hline
\end{tabular}

\section{Gulf of Mexico}

Bottlenose dolphin

Bottlenose dolphin

Bottlenose dolphin

Bottlenose dolphin

Bottlenose dolphin

Bottlenose dolphin

Bottlenose dolphin
Observed following trawlers. Shrimp found in stomach. Gunter (1942) Believed to damage nets.

Reported to damage nets. Could be made to move with rifle shots.

Gunter (1944)

Gunter (1951) shrimp in stomachs.

Reported to distinguish changes of boat operation.

Gunter (1954)

Observed to feed on trash fish off northeast coast of Florida, and to feed on catfish while operating shrimp boats were nearby.

Caldwell and Caldwell (1972)

Hogan (MS 1975) Seen following trawling boats; spent more time socializing near boats than eating discarded fish.

Categorized behaviors related to shrimp boats as: Leatherwood (1975) foraging behind working shrimp boats, feeding on trash fish, and feeding on fish attracted to nonworking shrimpers 
APPENDIX 3. (continued). Accounts of cetaceans feeding in association with trawls, reported geographically.

\begin{tabular}{|c|c|c|}
\hline Species & Interaction & Source(s) \\
\hline \multicolumn{3}{|c|}{ Gulf of Mexico } \\
\hline $\begin{array}{l}\text { Bottlenose } \\
\text { dolphin }\end{array}$ & $\begin{array}{l}\text { Observed feeding behind shrimp boats that had moved } \\
\text { from sounds to marsh in Mississippi. }\end{array}$ & $\begin{array}{l}\text { Leatherwood and Platter } \\
\text { (1975) }\end{array}$ \\
\hline $\begin{array}{l}\text { Bottlenose } \\
\text { dolphin }\end{array}$ & $\begin{array}{l}\text { Dolphins' activities completely dominated by shrimp } \\
\text { boats. }\end{array}$ & Shane (MS 1977) \\
\hline $\begin{array}{l}\text { Bottlenose } \\
\text { dolphin }\end{array}$ & $\begin{array}{l}\text { Detailed accounts of dolphin behaviors around } \\
\text { shrimp boats. Mother/calf pairs fed behind shrimp } \\
\text { boats; feeding as early as } 0545 \text { and continued past } \\
2200 \text {; following boat seemed preferable to eating trash } \\
\text { fish. Late spring to early fall, most dolphins } \\
\text { observed feeding in association with shrimp boats. }\end{array}$ & Gruber (MS 1981) \\
\hline $\begin{array}{l}\text { Bottlenose } \\
\text { dolphin }\end{array}$ & $\begin{array}{l}\text { Fed in association with shrimp boats in Mobile } \\
\text { Bay, Alabama. }\end{array}$ & Goodwin (MS 1985) \\
\hline $\begin{array}{l}\text { Bottlenose } \\
\text { dolphin }\end{array}$ & Associated with shrimp boats in Galveston Bay, Texas. & Henningsen (MS 1991) \\
\hline $\begin{array}{l}\text { Bottlenose } \\
\text { dolphin }\end{array}$ & $\begin{array}{l}\text { Detailed accounts of dolphin behaviors around shrimp } \\
\text { boats in Campeche Bay. Dolphins responded to motor } \\
\text { changes associated with changes in boat operation. } \\
\text { Observed feeding almost exclusively on bycatch. } \\
\text { Observations of feeding at night near working shrimp } \\
\text { boats. }\end{array}$ & $\begin{array}{l}\text { Delgado-Estrella } \\
\text { (MS 1991) }\end{array}$ \\
\hline $\begin{array}{l}\text { Bottlenose } \\
\text { dolphin }\end{array}$ & $\begin{array}{l}\text { Group of } 7 \text { young dolphins followed groundfish trawl } \\
\text { in Gulf of Mexico. }\end{array}$ & $\begin{array}{l}\text { C. Pharr, NMFS, } \\
\text { pers. comm. (1991) }\end{array}$ \\
\hline $\begin{array}{l}\text { Bottlenose } \\
\text { dolphin }\end{array}$ & $\begin{array}{l}\text { Detailed accounts of dolphin behaviors around } \\
\text { shrimp boats. Movements of dolphins did not appear } \\
\text { to be linked to changes in shrimp boat stages. } \\
\text { Speculated that females with calves may be } \\
\text { taking advantage of concentrated food resource provided } \\
\text { by shrimp boats to meet increased energetic needs due } \\
\text { to lactation. }\end{array}$ & Fertl (MS 1994) \\
\hline $\begin{array}{l}\text { Atlantic spotted } \\
\text { dolphin }\end{array}$ & Observed feeding in association with shrimp boats. & Delgado-Estrella (MS 1991) \\
\hline $\begin{array}{l}\text { Atlantic spotted } \\
\text { dolphin }\end{array}$ & $\begin{array}{l}\text { Followed large otter trawl to surface as it was hauled } \\
\text { in. Dolphins milled around the filled cod-end of } \\
\text { the net until it was actually brought on board. }\end{array}$ & Caldwell (1955) \\
\hline $\begin{array}{l}\text { Atlantic spotted } \\
\text { dolphin }\end{array}$ & $\begin{array}{l}\text { Mixed herd with bottlenose dolphins "biting the bag of } \\
\text { the trawl" and were seen in front of the bag. }\end{array}$ & $\begin{array}{l}\text { C. Rogers, pers. comm. } \\
\text { (1991) }\end{array}$ \\
\hline
\end{tabular}


APPENDIX 3. (continued). Accounts of cetaceans feeding in association with trawls, reported geographically.

\begin{tabular}{lll}
\hline \multicolumn{1}{c}{ Species } & \multicolumn{1}{c}{ Interaction } & \multicolumn{1}{c}{ Source(s) } \\
\hline $\begin{array}{l}\text { Bottlenose } \\
\text { dolphin }\end{array}$ & Obselize & \\
\hline
\end{tabular}

\section{Brazil}

Tucuxi

On at least 4 occasions, groups of up to 5 individuals

Barros and Teixeira (1994) observed close were to shrimp boats. No information is available on apparent association.

\section{Argentina}

Unidentifed Observed coming into and out of the mouth of the net, dolphins catching fish.

Crespo and Corcuera (1990)

\section{Southeastern United States (North Carolina)}

$\begin{array}{lll}\begin{array}{l}\text { Bottlenose } \\ \text { dolphin }\end{array} & \text { Observed feeding on discarded bycatch. } & \text { Davis (1988) } \\ \begin{array}{l}\text { Bottlenose } \\ \text { dolphin }\end{array} & \text { Observed following working trawlers. } & \begin{array}{l}\text { G. Rountree, pers. comm. } \\ \text { (1993) }\end{array}\end{array}$

\section{Northeast United States}

Pilot whale Active pursuit and opportunistic feeding in and around Waring et al. (1990) mouth of net during haulback.

\section{Scotian Shelf}

Fin whale "Feeding aft of codend."

Minke whale $\quad$ "Followed trawl at haulback."

Common "Followed trawl at haulback."

dolphin

Pilot whale

Northern bottle- 15 records of "followed trawl during haulback". nose whale
Following codend; following codend at haulback; feeding off fish at haulback of trawl; and variations thereof.
Can. Fed. Dept. Fish. and Oceans, unpubl. data

Can. Fed. Dept. Fish. and Oceans, unpubl. data

Can. Fed. Dept. Fish. and Oceans, unpubl. data

Can. Fed. Dept. Fish. and Oceans, unpubl. data

Can. Fed. Dept. Fish. and Oceans, unpubl. data

\section{North Sea}

Harbor porpoise Observed following the trawls, catching fish squeezed out through the meshes.
Clausen and Andersen (1988) 
APPENDIX 3. (continued). Accounts of cetaceans feeding in association with trawls, reported geographically.

\begin{tabular}{lll}
\hline \hline Species & Interaction & Source(s) \\
\hline & Northeast Atlantic (Celtic Sea) &
\end{tabular}

Atlantic white- Scavenged on discards

sided dolphin

Pilot whale Scavenged on catch pumped on board.

Killer whale

Bottlenose dolphin
Feeding on fish that slipped through the meshes or fell overboard, when the net was being hauled or shot.

30-40 dolphins scavenging behind a freezer trawler during hauling
A.S. Couperus, pers. comm (1994)

A.S. Couperus, pers. comm. (1994)

Couperus (1994)

A. S. Couperus, pers. comm. (1995)

\section{Mediterranean Region}

\begin{tabular}{lll}
$\begin{array}{l}\text { Bottlenose } \\
\text { dolphin }\end{array}$ & Suspected to feed on fish in trawl. & Di Natale (1989) \\
$\begin{array}{l}\text { Bottlenose } \\
\text { dolphin }\end{array}$ & Associated with shrimp boats. & $\begin{array}{l}\text { Bearzi and Notarbartolo di } \\
\text { Sciara (1992) }\end{array}$ \\
$\begin{array}{l}\text { Bottlenose } \\
\text { dolphin }\end{array}$ & Reported to harrass trawlers. & Northridge (1984) \\
$\begin{array}{l}\text { Bottlenose } \\
\text { dolphin }\end{array}$ & Feed in association with trawlers. & Goffman et al. (1995) \\
$\begin{array}{l}\text { Common dolphin } \\
\text { Striped dolphin }\end{array}$ & Feed in association with trawlers. & Goffman et al. (1995) \\
\hline
\end{tabular}

\section{West Africa}

Unidentifed Feeding at night on fish attracted to non-working Fulton (1976) dolphin trawler.

\section{South Africa}

Common dolphin Suspected to feed in association with trawls

V. Cockcroft, pers. comm. (1991)

\section{Western Sri Lanka}

Bottlenose Fed in mudline behind trawler.

Leatherwood et al. (1984) dolphin 
APPENDIX 3. (continued). Accounts of cetaceans feeding in association with trawls, reported geographically.

\begin{tabular}{llc}
\hline \hline \multicolumn{1}{c}{ Species } & \multicolumn{1}{c}{ Interaction } & \multicolumn{1}{c}{ Australia (Moreton Bay) } \\
\hline $\begin{array}{l}\text { Bottlenose } \\
\text { dolphin }\end{array}$ & $\begin{array}{l}\text { Attempted to establish a feeding station by feeding } \\
\text { dolphins with discards from stationary trawler. } \\
\text { Leading the animals with the trawler was not suc- } \\
\text { cessful for a variety of speculated reasons. }\end{array}$ & Green and Corkeron (1991) \\
$\begin{array}{l}\text { Indo-Pacific } \\
\begin{array}{l}\text { Hump-backed } \\
\text { dolphin }\end{array}\end{array}$ & $\begin{array}{l}\text { Reported to feed in mixed groups with bottlenose } \\
\text { dolphins behind trawlers. Would generally remain } \\
\text { farther from stern of trawler. Did not gain access } \\
\text { to preferred food items. }\end{array}$ & Corkeron (1990) \\
\hline
\end{tabular}

\section{Sources of personal communication and unpublished data:}

Canadian Federal Department of Fisheries and Oceans, P. O. Box 550, Station M, Halifax, Nova Scotia B3J 2S7

V. Cockcroft, Port Elizabeth Museum, P. O. Box 13147, Humewood 6013 South Africa

A.S. Couperus, Netherlands Insitute for Fisheries Research (RIVO-DLO), P. O. Box 68, 1970 AB Ijmuiden, The Netherlands

K. Dudzinski, Marine Mammal Research Program, Texas A \& M University, 4700 Avenue U, Galveston, TX 77551, USA

J. Heimlich-Boran, 7 Victoria St., Cambridge CB1 1JP, UK

T. Jefferson, Ocean Park Conservation Foundation, Ocean Park, Aberdeen, Hong Kong

C. Pharr, National Marine Fisheries Service, P. O. Drawer 1201, Pascagoula, MS 39568, USA

C. Rogers, National Marine Fisheries Service, P. O. Drawer 1201, Pascagoula, MS 39568, USA

G. Rountree, Cetacean Watch Project, 138 S. Colony Circle, Wilmington, NC 28409, USA 